Article

\title{
Sustainable Corporate Ownership Structures and Earnings Management in the Vietnamese Stock Market
}

\author{
Daeheon Choi ${ }^{1}$, Chune Young Chung ${ }^{2, *}$, Young-Eun Kim ${ }^{3}$, Ye Jun Kim ${ }^{4} \oplus$ \\ and Paul Moon Sub Choi ${ }^{5}$ (i) \\ 1 College of Business Administration, Kookmin University, Seongbuk-gu, Seoul 02707, Korea; \\ dhchoi@kookmin.ac.kr \\ 2 School of Business Administration, College of Business and Economics, Chung-Ang University, Dongjak-gu, \\ Seoul 06974, Korea \\ 3 Eller College of Management, The University of Arizona, Tucson, AZ 84721, USA; \\ lylakim18@email.arizona.edu \\ 4 Simon Business School, University of Rochester, Rochester, NY 14627, USA; yejun.kim@simon.rochester.edu \\ 5 College of Business Administration, Ewha Womans University, Seodaemun-gu, Seoul 03750, Korea; \\ paul.choi@ewha.ac.kr \\ * Correspondence: bizfinance@cau.ac.kr
}

Received: 29 May 2020; Accepted: 27 July 2020; Published: 29 July 2020

\begin{abstract}
We conducted an empirical analysis to verify the relationship between companies' ownership structures and earnings management. Our sample included 480 nonfinancial companies listed on Vietnam's Ho Chi Minh Stock Exchange and Hanoi Stock Exchange from 2012 to 2017, and our explanatory variables included several ratios, such as the controlling shareholders' stake, management ownership stake, state-owned stake, and foreign ownership stake, which represent different ownership structures. We examined the effects of these ratios on earnings management. Our results suggested that earnings management has a significant linear relationship with the state-owned and foreign ownership stakes. Our results can enhance the understanding of the role of companies' sustainable ownership structures in limiting earnings management, and they can contribute to future studies of the relationship between earnings management and corporate social responsibility and sustainability reporting assurance practices that focus on corporate ownership structures.
\end{abstract}

Keywords: sustainable corporate ownership structure; corporate governance; earnings management; Vietnamese market

\section{Introduction}

To develop in a market economy system, companies must be able to produce and operate successfully. Accounting profits are one of the most critical criteria for evaluating a company's performance and outlook. Profit is an economic tool that encourages productivity and affects improvements in management activities. In addition to company size, business areas, and attractive projects, profitability is an important indicator that most investors strongly consider when investing in companies. Thus, the transparency and disclosure quality of financial statements are critical to global investors, including those who invest in Vietnam. The quality of financial statements, especially profits, significantly affects stakeholders' decisions.

Healy and Wahlen [1] showed that managers intentionally modify information when evaluating economic transactions and reporting financial statements. These modifications involve adjusting management performance or accounting data-based contracts to achieve personal gains. 
Excessive earnings management may reduce the fairness, reliability, and comparability of accounting information, causing the users of this information to make suboptimal decisions. Excessive earnings management also provides an incentive for managers to act abnormally and adjust profits [2]. Although earnings management may induce the optimum level of profits in the short term, it has no effect on product improvements or organizational operations and may pose risks to a company's future development.

In the Vietnamese market, the adjustment of financial reporting has a significant impact on economic activities and is considered an important factor in financial scandals, as such adjustments may build public mistrust in the quality of financial statements. According to statistics from Vietstock (https//vietstock.vn), as of 8 April 2019, 451 (61.53\%) of the 733 listed companies audited prior to April 2018 had differences in their financial statements before and after being audited. Nine listed companies reported earnings but were found by audits to have actually suffered losses. In other cases, net profit increased by $724 \%$ after an audit. These events draw attention to financial statement quality and support the increasing concerns regarding earnings management.

Theoretically, investors are always willing to learn about a company's actual performance and expenditures. However, the separation of ownership and management in corporations creates a conflict of interest between these two parties. Owners want to collect information on operations, but managers tend to restrict the provision of such information or provide less reliable information. Thus, investors and financial analysts are passive when receiving information disclosed by listed companies. Indeed, the increasing number of financial scandals emphasizes the need to improve the quality of financial statements by establishing strict ownership structures. In the long run, an effective ownership structure can maximize company value and the transparency of information disclosure [3]. Several studies [3-9] focused on the role of the ownership structure within a company's overall operating system.

Using data on the Korea Corporate Governance Service's ownership structure assessment index from 2002 to 2005 to verify the effect of the ownership structure on earnings management, Son [4] identified fewer cases of earnings management in companies with stricter ownership structures. Similarly, Bae and Kim [5] found that companies that choose to improve their ownership structures as a method for controlling their operating systems have fewer managers and less actual earnings management.

Choi and Kim [6] showed that owner firms have lower absolute values of discretionary accruals, greater profit response factors, and greater discretionary accruals and cash flow response factors to share prices than manager firms have. They showed that the separation of ownership and management is a new, theoretical method for approaching the opportunistic earnings management problem.

Persons [7] noted that controlling shareholders' voting rights affects the board of directors' and shareholders' decisions. Shareholders have little incentive to receive earnings as a result of earnings management.

Ali et al. [8] showed that managers who own large stakes in a company have little incentive to manipulate accounting profits and can limit earnings management. Banderlipe and McReynald [9] and Alves [10] found that when management has a larger ownership stake earnings management is reduced and increasing management's ownership stake prevents managers from performing earnings management.

Generally, state-owned stakes are subject to low levels of management and monitoring [11], owing to increased management autonomy, and they may mitigate earnings management [12]. In addition, because the managers of state-owned enterprises may have contrasting interests owing to the temptations of various authorities [13], they manage conflicting views that may encourage data manipulation and lay the foundation for earnings management.

Seasholes [14] showed that the transaction performance of companies held by foreign investors is superior to that of companies held by domestic investors because the former have more knowledge and skills. Gillan and Starks [15] assumed that foreign investors influence management decisions by 
exercising their voting rights or by threatening to sell shares. Thus, the foreign ownership stake plays an important role in changing companies' operating systems. Chung et al. [16] showed that the foreign ownership stake blocks managers' opportunistic behaviors and reduces discretionary accruals.

We examined whether companies' earnings management differs according to the type of ownership stake. By determining whether the type or amount of ownership stake affects earnings management negatively or positively, we expected to enhance the understanding of the role of a company's ownership structure and identify alternatives that can improve future policies.

We examined the effects of corporate ownership structures on managers' earnings management. For this purpose, we present the correlations between discretionary accruals and the stakes of different types of shareholders, including controlling shareholders, managers, the state, and foreign investors. Using a regression formula following the modified Jones model and based on previous studies, we measured discretionary accruals. Our sample included 480 nonfinancial companies listed on Vietnam's Ho Chi Minh Stock Exchange and Hanoi Stock Exchange from 2012 to 2017.

We also suggest new directions for research investigating the relationship between earnings management and companies' corporate social responsibility (CSR) and sustainability reporting assurance (SRA) practices. It would be interesting to study this relationship within the context of the abovementioned corporate ownership structures.

The remainder of this paper consists of five parts. In Section 2, we present the background and purpose of our study and describe our methodology and study composition. In Section 3, we examine previous studies. Next, we set our hypotheses, define and measure our variables and sample, and discuss our demonstration test models in Section 4. In Section 5, we present the results of our empirical analysis and conduct additional analyses. Finally, in Section 6, we summarize our results and conclude the paper.

\section{Background: The Vietnamese Stock Market}

\subsection{Vietnamese Stock Market}

The Vietnamese economy began attracting foreign investment 31 years ago, and the Vietnamese stock market was established and developed 23 years ago. By expanding the mid- to long-term channel for capital procurement, the stock market has contributed to Vietnam's industrialization and modernization, which has led to several achievements. Capitalization in Vietnam's stock market accounted for $22.7 \%$ of gross domestic product (GDP) in 2006 and has increased around 17 times over the past decade to $78.5 \%$ as of the end of June 2019, exceeding the 2020 government target.

Vietnam's economy has developed significantly thanks to Doi Moi, a model for economic revolution that the country adopted in 1986. The privatization model utilized in 1992 advocated selling stakes in state-owned enterprises to employees and individuals and turning them into corporations. The privatization process included several stages, each with different achievements. The pilot stage (1992-1996) began on 8 June 1992, following an official announcement by the prime minister. Among the targets for privatization, which included small- and medium-sized state-owned enterprises (except for strategic companies) in the transportation, footwear, machinery, and food processing industries, only five were privatized. The second stage (1996-1998) began on 7 May 1996 under Decree 28/1996/ND-CP, and 25 state-owned enterprises were privatized as a result. These two stages were so inefficient that the government enacted Decree 44/1998/ND-CP on 29 June 1998. This decree was regarded as Vietnam's first legal framework for privatization, and it provided a clear framework for privatizing state-owned enterprises. As a result of this new decree, the number of state-owned enterprises that were privatized drastically increased from 1998 to 2001, reaching a total of 758 . Decree 64/2002/ND-CP and Decree 187/2004/ND-CP further accelerated privatization from 2002 to 2005, resulting in 3055 privatizations by the end of 2005. In Vietnam, privatization is considered one of the most important policies for economic revolution because the number of enterprises with only 
state-owned capital was significantly reduced from more than 12,000 in the 1990s to 595 in 2018 as a result of this process.

The Vietnamese government established two stock exchanges, the Ho Chi Minh Stock Exchange (HOSE or HSX) and the Hanoi Stock Exchange (HNX), to create an effective platform for financing. These two stock exchanges have supported Vietnam's economy and accelerated economic growth. Their total market value was 559,996.9 billion dong (24.348 billion United States Dollar (USD)) at the end of November 2019, which was plus 10.18\% year over year and accounted for 101.04\% of GDP. Private enterprises' financing through stock and bond issuances rose more than $70 \%$ in 2017 and 30\% in 2018 to around $\$ 3.7$ billion. Thus, Vietnam has become the most successful country in Southeast Asia in terms of financing capital.

Vietnam has attracted large amounts of foreign financing and has facilitated trading by local investors. Owing to a significant increase in the value of the Vietnamese stock market in 2007, Vietnam was able to join the World Trade Organization (WTO), the world's largest commercial organization. Vietnam's becoming a member of the WTO was highly recognized by both domestic and foreign newspapers. The International Monetary Fund (IMF) described Vietnam as the "New Miracle Asian" (2006), and Citigroup called Vietnam the "New Power in Southeast Asia" (2006).

Despite this success, Vietnam's economic growth rate shrank to $6.3 \%$ in 2008 and $5.3 \%$ in 2009 , owing to the 2008 global financial crisis. Although its economy slightly recovered in $2010(6.8 \%)$, Vietnam's economic growth rate again slowed down in 2011 (5.9\%) and $2012(5.0 \%)$, and its stock market fell to 235 points after reaching a record high of 1171 points in March 2007. Furthermore, new governance rules, such as the establishment of formal risk management committees, an increase in the number of board members, the establishment of an independent control board reporting directly to the board of directors, and active communication among executives, were set for listed companies.

Nevertheless, the Vietnamese stock market continues to attract foreign indirect financing. In fact, from 2016 to the present, the level of foreign indirect financing has remained relatively high (around $\$ 2$ billion on average). Although global markets fluctuate sharply and investors tend to withdraw capital from emerging markets, Vietnam is still recognized as a secure market for foreign investors. Indeed, indirect financing amounted to $\$ 1.8$ billion in the first half of 2019. By the end of March 2019, the Vietnamese stock market had 2.2 million trading accounts, 2.19 million of which were owned by individual investors, 9492 by institutional investors, and 29,072 by foreign investors.

\subsection{Vietnamese Corporate Ownership Structure}

The rapid development in the Vietnamese stock market has led to calls for company disclosures to support and promote market operations. The Vietnamese government has set regulations on corporate ownership structures since early 2005. Vietnam's Enterprise Law (2005) is the most important regulation that forms the basis for Vietnamese companies' ownership structures. According to this law, a company has obligations and certain authorities to determine internal ownership structure issues through constitutions, including shareholders' rights and obligations, its ownership structure, and rules for settling internal disagreements. Code 2007 and Amendment 2012 provide guidelines to strengthen the quality of listed companies' disclosures. These standards and amendments provide key principles regarding the corporate ownership structures of listed companies, including principles for (1) internal ownership structures, (2) shareholders' rights, (3) transactions between parties with conflicts of interest, and (4) transparency of disclosures.

According to Code 2007 and Amendment 2012, the internal structures of listed companies include general shareholders' meetings, executives, the chairman of the board or CEO, and the control board. However, the Enterprise Law (2005) does not provide clear definitions of board members and managers. This lack of clear definitions may lead to a lack of responsibility for managers in Vietnam and a lack of investor protection. The CEO and control board have the right to attend management meetings and participate in discussions, but they do not have the right to vote. Thus, the control board can supervise and monitor executives, and the CEO can present opinions and receive feedback from executives. 
In addition, the members of the board have the right to request information from the CEO and other managers regarding the company's operations. Based on Organization for Economic Cooperation and Development (OECD) principles, listed companies' internal ownership structures should ensure effective monitoring and responsibility to shareholders. However, according to the Enterprise Law and Code, the ownership structure of Vietnam's listed companies lacks efficiency and responsibility [17]. The Enterprise Law strengthens the investor protection mechanism and gives shareholders the right to attend shareholder meetings and to vote. However, it limits shareholders from requesting shareholder meetings unless they present evidence. Furthermore, shareholders in Vietnam do not have the right to request shareholder meetings under the Code [17].

Even with these various regulations and efforts to make Vietnam's financial environment transparent, the quality of listed companies' financial statements is poor and differs before and after audits [18]. In other words, the Vietnamese corporate ownership structure lacks flexibility, responsibility, and efficiency and does not meet detailed ownership structure requirements [17].

\subsection{Ownership Structure}

With the aim of improving corporate performance, the privatization process started in 1992 helped to transform the ownership structures of state-owned enterprises by selling state-owned stakes in these enterprises to foreign investors, resulting in an increase in the number of ownership types. In particular, Vietnam's joining the WTO led to an increase in foreign investment flowing into the country. Vietnam currently has a transitional economy. Previously, state-owned enterprises were the main players in the ownership system, but the range of ownership structures is currently expanding, and the new system involves large numbers of firms with various ownership types, including state-owned enterprises, multinational corporations (all foreign-invested), joint ventures (between foreign investors and state-owned enterprises), and private enterprises.

Although the number of state-owned companies held by nongovernmental institutions is increasing, state ownership still plays an important role in most companies listed on the Ho Chi Minh Stock Exchange and the Hanoi Stock Exchange. In our sample of 480 companies listed on the two Vietnamese stock exchanges from 2012 to 2017, state ownership remained dominant, at an average of around $21.2 \%$ of companies.

Prior to the implementation of the Doi Moi economic revolution in 1985, the only economic sectors operating legally in Vietnam were state-owned enterprises and other cooperative organizations. Private ownership was regarded as an enemy of socialism. Industries operated by state-owned enterprises were regarded as critical to the national economy and were activated under plans set up by the central government. In 1986, Vietnam started to reform its economy from a centrally planned economy to a socialist-centric market economy by adopting the Doi Moi reforms. State-owned enterprises of strategic importance were transferred to corporations while their shares were held by the government. The transferred corporations started to list themselves on stock exchanges. According to the Treasury Department, 538 state-owned enterprises were privatized between 2011 and 2019. In 2003 , the state owned a $55.4 \%$ stake in state-owned companies, and this ratio was still high in 2004 , at $50 \%$, but it fell to $41 \%$ by 2018 .

For enterprises with high ratios of state ownership, state management rights and ownership rights are not separated because the state-owned stake acts as a regulator. When controlling shareholders hold a high proportion of a company's stakes, they can reject important investment decisions, allowing them to intentionally intervene in operational activities. On a macro level, manipulation is likely to occur in certain institutions if the state plays a double role as the owner of state-owned enterprises and as the top administrative body. If managers are free to operate at their own discretion and are not monitored, they are likely to abuse their authority and take advantages to gain personal profits. Enterprises with large state-owned stakes may not be disciplined even when they cannot pay capital on time because the capital is supported by the state. Such enterprises depend less on foreign capital and are, therefore, likely to avoid disclosing information and to have poor-quality financial statements [19]. 
Enterprises with high levels of state ownership in Vietnam tend to be less transparent. One of the main reasons for this characteristic is the information asymmetry among internal and external investors regarding such enterprises' actual and future values. When this information is incomplete or not transparent and the rights of minority shareholders are not protected, investors will not buy stakes in the enterprises because doing so requires taking great risks. As a result, in most cases, these stakes are held by executers with internal information and their relatives.

We used the difference-in-differences (DID) method to assess the performance of companies after Vietnam's privatization process by identifying the performance of 121 companies, following Loc et al. [20] (p. 158), and we confirmed the effects of macroeconomic factors and the privatization processes. Our results showed that corporate profit increases when privatization is actively and transparently implemented. Indeed, companies with high ratios of state ownership are subject to various informal interventions (e.g., political interventions) and to additional legal and administrative regulations. Cook and Kirkpatrick [21] showed that political intervention is the main cause of inefficiency in state-owned enterprises. Political intervention occurs when people with little to no operational experience are hired in political positions and make important decisions, such as hiring, trading, and asset evaluation. Fredrick [22] reconfirmed that companies under heavy control of the state in Vietnam may have less operational effectiveness. When state ownership falls after privatization, companies generally show increased profitability, enhanced liquidity, improved capital management, increased levels of repayment risk, and increased leverage [23].

The privatization process, a government policy that encouraged the transformation of corporate ownership structures, has accelerated the increase in foreign ownership stakes. According to the World Bank, the inflow of foreign portfolio investment into Vietnam increased drastically from 2007 to 2015. This increase was a significant achievement and was based on Vietnam's political stability and high economic growth over the past decades. The initial legal provision limiting foreign ownership in listed companies was introduced in 2009. Under this provision, foreign investors cannot hold more than $49 \%$ of total shares outstanding, resulting in several restrictions on such investors. The aim of the provision was to protect domestic investors, but it actually served as an obstacle to the development of listed companies. These restrictions reduced liquidity in the stock market by preventing foreign investors' excessive trading. A new legal system that eases foreign ownership restrictions was introduced in 2015 to attract foreign investment. This provision claims that foreign investors can hold all of a company's shares if the easing of foreign limits is approved at the annual shareholders' meeting. This new legal system provides listed companies with access to foreign capital and encourages them to improve management performance. However, the law clearly names specific industries that may ease foreign investors' holding limits.

Vietnam is still recognized as an attractive market for foreign investors. According to preliminary statistics released by Vietnam Statistics (20 December 2019), newly registered foreign direct investment (FDI) and incremental FDI amounted to $\$ 1.65$ billion (3883 cases) and $\$ 5.8$ billion (1381 cases), respectively, with total FDI of $\$ 22.54$ billion. Of the 81 countries from which Vietnam attracted investment in 2019, South Korea ranked first with $\$ 3.6688$ billion (21.9\%), followed by Hong Kong with $\$ 2.8119$ billion (16.8\%), China with $\$ 2.3734$ billion (14.2\%), Singapore with $\$ 2.1$ billion (12.5\%), and Japan with $\$ 1.8207$ billion (10.9\%).

Another characteristic of the Vietnamese market is that players participate in corporate operations as both controlling shareholders and managers. According to Vietnam's Law on Securities, a controlling shareholder is one who owns a $5 \%$ or greater stake in a company and has voting rights. The law specifies the rights of controlling shareholders according to their stakes. Specifically, shareholders with $36 \%$ stakes may refuse important decisions, shareholders with $51 \%$ stakes may propose decisions, and shareholders with 75\% stakes may pass all decisions. Controlling shareholders serve in similar roles to those of CEOs or managers and participate in management activities. Kim and Lyn [24] show that internal ownership is high when the management's ownership stake is $25 \%$ or higher and low when the management's ownership stake is less than $5 \%$. Majority shareholders can control a company 
because that company's top decision-making and remaining profit-taking rights are given to a single individual. Supervisory issues regarding asset ownership or opportunistic behavior do not arise from the separation of ownership and management.

\section{Previous Studies and Hypothesis Setting}

\subsection{Theories of Earnings Management}

Schipper [25] showed that managers intentionally adjust profits and intervene in providing financial information to achieve personal objectives. Earnings management reflects managers' choice of accounting methods to gain personal profits or increase a company's market value [26].

Levit [27] proposed that earnings management is forgery of accounting information because it means that managers are intentionally modifying their accounting information. Thus, the income statement reflects managers' wishes rather than the company's actual financial situation.

Healy and Wahlen [1] showed that managers adjust profits when they want to deceive stakeholders regarding production performance by using internal contracts or transactions or when they want to make contracts that require certain levels of accounting profits.

Akers et al. [28] defined earnings management as a manager manipulating an income statement by selecting a particular accounting method, accelerating or delaying transaction records, or using a specific method designed to affect short-term income.

Beneish [29] defined earnings management as an intervention that provides investors and stakeholders with useful financial information about a company's production situation so that they can make financial decisions.

Previous studies suggested that earnings management can be carried out using one of two methods. One is accrual-based earnings management (AEM), which uses accounting methods for earnings management, and the other is real earnings management (REM).

The AEM method adjusts profits by flexibly selecting accounting methods and estimates within the scope of generally accepted accounting principles [30]. Managers manipulate income statements by altering accounting standards that require prudence, such as estimates of bad debt expenses, the value of impaired tangible assets, and the value of liquidated tangible assets. The AEM method manipulates these estimates to affect actual management performance [31].

Schipper [25] shows that the REM method adjusts profits and related figures through financial and investment decisions. The REM method is defined as a management activity that alters the revenue achieved by reducing costs (e.g., advertising, research and development, and sales management costs), either by overproducing or by reducing discretionary costs. In other words, REM is business management that deviates from normal management practices and results in second-best management performance [32].

Jensen and Meckling's [33] agency theory is considered the basic theory of companies' profit-adjusting behavior. The separation of ownership and management is one of the characteristics of a corporation. This separation causes problems when managers run a corporation on behalf of an owner because managers may take actions to maximize their own profits rather than the owners' profits. This separation also results in information asymmetry. Because managers have better access to financial information, they tend to provide limited information or hide information to gain personal profits. If a company's financial statements do not truly reflect management's performance, they do not provide useful information to owners. Thus, a mechanism to monitor managers' decisions is necessary to increase shareholder value and to transparently disclose accurate financial statement information. Controlling shareholders can control and manage corporations to protect investors. In addition, both foreign investors with financial resources and professional information and institutional investors can monitor managers and reduce agency problems. Agency theory emphasizes the importance of a mechanism that motivates managers with incentives for an ownership stake or that increases institutional and foreign investors' ownership stakes to overcome this conflict of interest. 


\subsection{Linear Studies on Controlling Shareholders and Earnings Management}

The corporate ownership structure emphasizes the role of controlling shareholders in supervision and management [34]. Even when monitoring managers is impossible, controlling shareholders may entrust control to a third party by sharing the profits from their stakes with bidders. Strengthening controlling shareholders' power also helps reduce conflicts between shareholders and managers.

Controlling shareholders not only control managers' behavior but also actively participate in business activities. Choi and Kim [6] showed that companies with large proportions of controlling shareholders have lower absolute values of discretionary accruals, and their discretionary accruals and cash flows react more strongly to share prices.

Focusing on the relationship between controlling shareholders' stakes and managers' earnings management, Park [35] analyzed nonfinancial firms listed on the Korea Stock Exchange from 1999 to 2000. The higher the controlling shareholders' stake is, the more likely managers are to adjust profits. When only considering the size of earnings management, the absolute value of the controlling shareholders' stake is negatively (-) correlated with discretionary accruals.

Iturriaga and Hoffmann [36] analyzed the impacts of two earnings management control mechanisms, the capital structure and the ownership structure, on the Chilean capital market, which covers fast-developing, high-ownership, and low-leverage companies. They found that controlling shareholders' stakes limits earnings management by encouraging the monitoring of managers. Within the Chilean market, which lacks investor protection policies, controlling shareholders make an effort to protect their own interests.

Roodposhti and Chashmi [37] showed that various ownership structure characteristics (including the controlling shareholders' stake, having an independent board of directors, CEO dominance, and the institutional shareholders' stake) affect earnings management. Their sample included 196 companies listed on the Tehran Stock Market from 2004 to 2008, and the control variables included company size and leverage. They observed more earnings management in companies with higher CEO-board duality and higher institutional shareholders' stakes and less earnings management in companies with higher controlling shareholders' stakes and independent boards of directors. One reason for these findings is that managers lose control of controlling shareholders or are continuously monitored by them. Another reason is that higher controlling shareholders' stakes lead to greater monitoring of managers, resulting in less motivation for managers to manipulate accounting profits and unstable profits.

By considering corporate ownership structures in the Portuguese capital market, Alves [10] showed that the controlling shareholders' stake has a positive impact on the quality of profit information and improves the quality of financial information and market value because the controlling shareholders' stake has direct and indirect effects on management decisions. Consequently, the controlling shareholders' stake is crucial for limiting earnings management in Portuguese companies.

Additionally, previous studies on earnings management found negative relationships between earnings management and majority shareholders' stakes [38-41].

Lee and Park [42] examined earnings management by analyzing 67 companies whose controlling shareholders' stakes increased in 2001 and 2002 and 43 companies whose controlling shareholders' stakes decreased in the same period. They found that the companies whose controlling shareholders' stakes increased had lower profits in the years before these stakes increased.

\subsection{Hypothesis Setting on Controlling Shareholders and Earnings Management}

Controlling shareholders have strong motivations to actively control and manage companies to protect their investments [34]. Smith [12] studied the effects of owner firms and manager firms on earnings management and showed that earnings management is more severe in the absence of controlling shareholders than in their presence. Smith [12] concluded that controlling shareholders act as monitors to maximize profits rather than to gain acceptable profits. Controlling shareholders control 
managers by reducing their opportunities to perform earnings management [43]. The controlling ownership stake is related to low spending on activities in the range of managers' private interests [44].

However, majority and minority shareholders in companies with concentrated ownership may experience conflicts of interest. Shleifer and Vishny [34] showed that controlling shareholders can exercise control to generate profits and can sometimes take minority shareholders' profits. Thus, controlling shareholders can hinder management and can encourage managers to maximize their own profits through earnings management [45].

Ali et al. [8], Roodposhti and Chashmi [37], Iturriaga and Hoffmann [36], and Alves [10] showed that managers either lose control of controlling shareholders or are under constant surveillance by controlling shareholders based on the negative relationship between the controlling ownership stake and earnings management. As the controlling ownership stake increases, the quality of financial information and the firm's market value improve, reducing earnings management and increasing stable profits.

Accordingly, we set Hypothesis 1.

Hypothesis 1. The controlling ownership stake has a negative (-) effect on earnings management.

\subsection{Linear Studies on Managers' Stakes and Earnings Management}

According to Jensen and Meckling [33], agency theory suggests that incentives should be provided to maximize company value because high management ownership stakes affect a company's wealth. Profits correspond to shareholders' gains when a manager acquires company shares, limiting managers' opportunistic behavior and reducing the size of agency costs.

Warfield et al. [38] showed that the separation of ownership and management and issues with managerial incentives fall within the scope of property rights' contracts. Because the terms of these contracts limit the earnings management incentives for managers to select specific accounting methods, the usefulness of information increases and absolute discretionary accruals decrease as the management ownership stake increases.

Gillian et al. [46] demonstrated a potential nonlinear relationship between the usefulness of revenue information and the management ownership stake. At a low level of management ownership, the usefulness of information increases with the management ownership stake, but at a high level of management ownership, increasing managers' ownership level becomes ineffective in encouraging managers to maximize company value.

Ali et al. [8] empirically analyzed 1001 nonfinancial companies listed in Malaysia from 2002 to 2003 and showed that managers' ownership can limit earnings management. Their study also showed that company size eases the relationship between the management ownership stake and discretionary accruals. In other words, although the management ownership stake may reduce profit-adjusting behavior, other factors, such as company size, may also affect such behavior. Management ownership is an effective monitoring mechanism, especially for small companies. Thus, small companies should encourage greater management ownership stakes to make up for their weak corporate ownership structures.

Alves [10] studied the relationship between corporate ownership structures and earnings management in the Portuguese capital market. According to the results of the empirical analysis, ownership structure factors, such as the management ownership stake, controlling shareholders' stake, and institutional ownership stake, affect earnings management. In particular, the management ownership stake interferes with earnings management. These results are consistent with the interest hypothesis that a manager who owns a large stake in a company has less incentive to manipulate accounting information as well as with the efficient monitoring hypothesis that controlling shareholders reduce the scope for management opportunism. The results also showed that earnings management 
decreases when operating cash flows are high and increases when political costs, the number of directors, and leverage are high.

McConnell and Servaes [47] found a positive relationship between Tobin's Q and directors' stakes, and Klein [48] showed that the higher the CEO's stake is, the lower opportunistic earnings management is.

Ali et al. [8], Banderlipe and McReynald [9], Dhaliwal et al. [49], Ebrahim [50], and Warfield et al. [38] showed that a higher management ownership stake is related to a lower level of earnings management.

\subsection{Hypothesis Setting on Managers' Stakes and Earnings Management}

The management ownership stake represents managers' profits from their ownership stakes in the company. Agency theory describes a conflict of interest between managers and shareholders when ownership and management are separated. However, agency problems can be reduced when managers' profits are in line with a company's profits. Managers use their privileges to deviate from the goal of shareholder wealth maximization when they have no stake in the company [33]. Warfield et al. [38] showed that shareholders' and managers' interests converge when managers have a portion of ownership. Studies consistent with agency theory show that managers tend to maximize company value and have little incentive to adjust profits when they have high ownership stakes in a company. The management ownership stake, which affects the effectiveness of monitoring functions, is an important characteristic in the financial management process [51].

Conversely, Morck et al. [52] demonstrated a curved rather than a linear relationship between the management ownership stake and financial statements. Managers have a personal incentive to readjust financial figures by not disclosing important information to other shareholders when the management ownership stake increases [53]. Thus, the size of the management ownership stake is related to financial manipulation because it represents the degree of honesty to other shareholders.

Warfield et al. [38] found a negative relationship between the management ownership stake and earnings management. Ali et al. [8] showed that the higher the management ownership stake is, the lower the manager's incentive to adjust profits is.

Accordingly, we set Hypothesis 2.

Hypothesis 2. The management ownership stake has a negative effect on earnings management.

\subsection{Linear Studies on the State-Owned Stake and Earnings Management}

Extensive research has been conducted on the impact of state ownership on companies' performance, and studies have found conflicting results.

$\mathrm{Xu}$ and Wang [54], Qi et al. [55], Sun and Tong [56], and Bai et al. [57] found negative correlations between the state-owned stake in a company and the company's performance. Conversely, Liu et al. [58] studed 1034 companies in China and showed that company performance is higher at the optimal level of state-owned shares.

Because state-owned shares play an important role in most Chinese state-owned enterprises, managers of these enterprises are likely to hide enterprise performance and restrict information disclosures for the benefit of shareholders [59].

Bauwhede et al. [60] studed financial data from companies in the Belgian market. They showed that the state-owned stake provides an incentive to increase profits, positively affecting discretionary accruals. They also showed that both private and state-owned enterprises participate in income smoothing and opportunistic earnings management to achieve the benchmark target from the previous year.

Ding et al. [61] studied the relationship between earnings management and ownership structures. Their sample included 273 state-owned and private enterprises, and they found a nonlinear, inverted U-shaped relationship between earnings management and ownership concentration. 
The entrenchment effect of the ownership concentration on earnings management is stronger for state-owned enterprises than for private enterprises.

Chen et al. [62] observed a positive correlation between the state-owned stake in a company and earnings management. China's central government creates regulations to protect investors in the capital market and to guarantee listed companies, whereas local governments participate in the competition among judicial powers to secure more capital. In addition, moral hazard exists because local governments act as agents of the central government. Local governments provide subsidies to help raise profits beyond the regulatory standard for rights and delisting. This earnings management collusion between local governments and listed companies is mainly found among companies controlled by local governments.

The main organizational structures in the Chinese market are state-owned stakes and private networks. Wang and Campbell [63] studied Chinese listed companies' financial data from 1998 to 2009 to examine the impact of International Financial Reporting Standards (IFRS), the state-owned stake, and boards of directors on earnings management. They concluded that although the state-owned stake hinders earnings management to some extent in China's current environment, the implementation of IFRS does not interfere with earnings management.

Ben-Nasr et al. [64] studied a unique dataset of 350 privatized enterprises in 45 countries and find that the state-owned stake is related to low profits and the possibility of high earnings management. In general, countries engage in potential tunneling activities to support companies for political purposes. However, they tend to conceal this fact by encouraging privatized enterprises to lower the quality of their budgets.

Poli [65] found a positive correlation between the state-owned stake and earnings management in the Italian capital market.

Chung et al. [66] studied the impact of the state-owned stake on China's earnings management by classifying 557 companies listed on the Shanghai Stock Exchange and the Shenzhen Stock Exchange from 1998 to 2006 into state-owned and private enterprises. They showed that state-owned enterprises have lower cumulative levels of earnings management than private enterprises have, which contradicts the conventional wisdom and the authors' hypothesis that state ownership is the basis for inefficient businesses. Chung et al. [66] explained that the government's protection of state-owned enterprises plays an important role in preventing managers from manipulating information.

\subsection{Hypothesis Setting on the State-Owned Stake and Earnings Management}

Previous studies on the impact of the state-owned stake on profit-adjusting behavior offer limited and inconsistent results. Specifically, Chung et al. [66] reported that the state-owned stake negatively impacts earnings management because governments' protection of state-owned enterprises reduces managers' manipulative behavior. Additionally, Firth et al. [67] reported that earnings management is observed more frequently within state-owned enterprises than within nonstate-owned enterprises. Liu and $\mathrm{Lu}$ [68] reported no correlation between earnings management and the state-owned stake.

It is widely believed that state-owned enterprises are likely to adjust profits [66]. Managers are likely to act in their best interests based on ineffective management, inadequate market discipline, multiple conflicts of interest, and the reporting of accounting information for the benefit of the governing authorities [66]. Moreover, enterprises with high state-owned stakes have lower incentives to report useful profit information owing to the potential for political gain $[69,70]$.

In Vietnam, the government is privatizing state-owned enterprises such that it holds high stakes in corporations throughout this reform process. However, the organizational structures and management mechanisms of privatized state-owned enterprises are yet to deviate from a centralized system because privatized state-owned enterprises have long been subsidized by the government. This situation results in poor management of state-owned enterprises [71] and in managers' opportunistic behavior through earnings management. 
In addition, Bauwhede et al. [60], Chen et al. [62], and Ben-Nasr et al. [64] showed that the state-owned stake is significantly positively $(+)$ correlated with earnings management.

Accordingly, we set Hypothesis 3.

Hypothesis 3. The state-owned stake has a positive (+) effect on earnings management.

\subsection{Linear Studies on Foreign Investors' Stakes and Earnings Management}

Sueyoshi et al. [72] showed that foreign investment improves the management performance of Japanese manufacturing companies. Thus, they argued that Japanese companies should accept more foreign investors and pay attention to their opinions because companies can be operated internationally at low cost and because foreign investors' opinions are useful for international management.

When foreign investment is allowed, it is important to establish investment techniques that stabilize the market and to improve the quality of the stock market. In addition, foreign capital increases managers' stewardship responsibility and the quality of accounting profits through the monitoring of management. From this perspective, Jeon [73] showed that foreign investors who monitor company management improve the quality of accounting profits, resulting in increases in foreign capital and decreases in earnings management.

Companies with large foreign ownership stakes disclose highly reliable financial information and have lower levels of information asymmetry. Chung et al. [16] used the Jones model to estimate discretionary accruals. Their sample included listed companies on the Tokyo Stock Exchange from 1975 to 1998 but excluded companies in the financial, insurance, power, and gas sectors. They showed that the foreign ownership stake effectively controls discretionary accruals and provides useful information on company value and profitability to prevent private managerial opportunism.

Ahn et al. [74] showed that the higher the foreign ownership stake is, the lower the profit forecast error and discretionary accruals are. When foreign investors effectively perform external monitoring, a company's information environment improves because corporate asymmetry problems are solved and managers' moral hazard is reduced.

Kim and Yoon [75] studied whether improvements to the ownership structures of companies listed on the Korea Stock Exchange from 2004 to 2005 could ease earnings management. Dechow et al. [76] used a modified Jones model to estimate discretionary accruals for earnings management. They used an average difference test and the accounting analysis method to show that the independence of the board of directors, the concentration of ownership, foreign ownership, the leverage ratio, and company size greatly affect total and discretionary accruals.

Another study supports the idea that foreign investors demand higher quality accounting information to prevent the transfer of company resources to controlling managers. Ben-Nasr et al. [58] found a relationship between the foreign ownership stake and factors such as low discretionary accruals, high information availability, and high profit quality based on high profit persistence. This evidence suggests that the institutional environment affects the relationship between the foreign ownership stake and profit quality. In other words, foreign investment is related to high profits in companies from countries with stable governments and those with a low risk of government acceptance.

Klai and Omri [77] analyzed 22 companies listed on the Tunisian Stock Exchange from 1997 to 2007 to study the impact of a company's ownership structure on the quality of financial reporting. In particular, they focused on the characteristics of the board of directors and the ownership structure that affect both managers' profit-adjusting behavior and the quality of financial reporting. The empirical results suggested that certain ownership structures, including concentrated ownership and a lack of independence, are related to Tunisian companies' earnings management. Specifically, foreign investment, family investment, and ownership concentration lower the quality of financial reporting by increasing earnings management, whereas state ownership and institutional investment 
improve the quality of financial reporting by limiting earnings management. In addition, three control variables, namely company size, growth opportunities, and leverage, reduce earnings management.

\subsection{Hypothesis Setting on Foreign Investors' Stakes and Earnings Management}

Globally, foreign capital is playing an increasingly important role in countries' development. This foreign capital includes FDI and foreign portfolio investment (FPI). FDI capital plays a direct role in promoting production, whereas FPI capital has a positive impact on the development of the financial market, including improvements in operational efficiency and transparency and expansion of the market. FPI also assists domestic enterprises in accessing new capital and improves the quality of corporate ownership structures. Thus, opening the economy for national trade and foreign investment has caused significant changes to corporate ownership structures.

The liberalization of cross-border capital flows in developing countries is meaningful for two main reasons. First, compared to state-owned enterprises, foreign institutions are strongly motivated to monitor management activities to increase their investment returns. Second, compared to domestic investors, foreign investors in emerging markets have more effective tools for monitoring [78].

The foreign ownership stake reduces earnings management by helping to improve the transparency of information disclosures [67]. Companies with higher foreign ownership stakes have lower information asymmetry, which reduces managers' moral hazard, resulting in lower profit forecast errors and discretionary accruals [16,74].

Accordingly, we set Hypothesis 4.

Hypothesis 4. The foreign ownership stake has a negative (-) effect on earnings management.

\subsection{Linear Studies on CSR and Ownership Structures}

Kim et al. [79] investigated the relationship between CSR and firm value in the context of ownership structures. They focused on the ownership stakes of controlling and foreign shareholders and the value of the firm's CSR. They found that a higher controlling shareholders' ownership stake leads to lower CSR and firm value, but they found no evidence on the relationship between the foreign ownership stake and CSR and firm value.

Salvioni and Gennari [80] investigated the relationship between sustainability and corporate governance with a focus on ownership. They found that sustainability and CSR lead to the reformation of companies' ownership structures, which ensures fair disclosure and accountability.

\subsection{Linear Studies on CSR and Earnings Management}

Hummel and Ising [81] checked whether corporate sustainability performance is related to earnings management and found a negative relationship.

Grimaldi et al. [82] studied companies' sustainability engagement in line with the Sustainable Development Goals and its relationship with earnings management. Using a sample of companies on the Italian Stock Exchange, they found results suggesting that sustainability engagement and earnings management practices have a negative relationship.

\section{Research Design}

\subsection{Sample Selection}

Our sample included all companies listed on the Vietnam Stock Exchange from 2012 to 2017 that met the following criteria:

(1) Companies continuously listed on the Hanoi Stock Exchange or the Ho Chi Minh Stock Exchange from 2012 to 2017;

(2) Companies not in the financial industry; 
(3) Companies for which we had access to financial statement and ownership structure data between 2012 and 2017 for the empirical analysis.

We excluded the financial, securities, and insurance industries from our sample because their current regulations on financial statements are not consistent with those of other companies. (http://www.vietstock.vn) We collected financial statements and ownership structure data from a Vietnamese website. Our final sample of companies that met the criteria over the five years from 2012 to 2017 included 480 companies and 2382 company-year observations.

\subsection{Definition and Measurement of Variables}

\subsubsection{Earnings Management}

Chou et al. [83] showed that the basic principle of earnings management is to create a difference between accounting profits and actual cash flows. Total accruals (TA) refer to the difference in accounting profits due to adjustments by managers. Studies on profit-adjusting behavior decompose total accruals into discretionary and nondiscretionary accruals.

Several models, such as the modified Jones model [76] and the Jones-Return on Assets (ROA) model [84], have been developed to identify profit-adjusting behavior.

We used the modified Jones model (1995) to estimate earnings management in our study because it is conceptually superior to other models.

We used the adjusted Jones model for our regression analysis to estimate discretionary accruals. Nondiscretionary accruals (NDA) are estimated as follows.

$$
T A C_{i, t}=\alpha_{0}\left(\frac{1}{A_{i, t-1}}\right)+\alpha_{1}\left(\frac{\Delta R E V_{i, t}-\Delta R E C_{i, t}}{A_{i, t-1}}\right)+\alpha_{3}\left(\frac{P P E_{i, t}}{A_{i, t-1}}\right)+\epsilon_{i, t}
$$

Here,

$T A C_{i, t}$ : Total accruals of firm $i$ in period $t$;

$A_{i, t-1}$ : Total assets of firm $i$ in period $t-1$;

$\triangle R E V_{i, t}$ : Change in the net sales of firm $i$ in period $t$;

$\triangle R E C_{i, t}$ : Change in the credit purchases of firm $i$ in period $t$;

$P P E_{i, t}$ : Tangible assets of firm $i$ in period $t$;

Discretionary accruals $(D A)$ for each company are calculated as follows.

$$
A_{-} D A_{i, t}=\left\{T A C_{i, t}-\left[\hat{\alpha_{0}}\left(\frac{1}{A_{i, t-1}}\right)+\hat{\alpha_{1}}\left(\frac{\Delta R E V_{i, t}-\Delta R E C_{i, t}}{A_{i, t-1}}\right)+\hat{\alpha_{3}}\left(\frac{P P E_{i, t}}{A_{i, t-1}}\right)\right.\right.
$$

Discretionary accruals may be positive (+) or negative (-) depending on managers' adjustment purposes. Thus, we took the absolute value of $A_{-} D A_{i, t}$ and calculated discretionary accruals to measure the degree of earnings management regardless of its direction. The higher the discretionary accruals are, the more the company encourages earnings management.

\subsubsection{Independent and Control Variables}

Independent Variables

(1) Controlling Shareholders' Stake (CO)

A controlling shareholder is a shareholder who owns more than $5 \%$ of a company's shares. Controlling shareholders' large stakes motivate them to monitor managers [85]. Controlling interest, which is the percentage of all issued shares held by controlling shareholders, reduces earnings management $[10,36,37]$. 
(2) Management Ownership Stake

Owner-managers are managers who have stakes in the company and take responsibility for management. The higher the management ownership stake is, the lower the incentive to adjust profits is $[8,10,38]$. The management ownership stake is the percentage of all issued shares held by owner-managers.

(3) State-Owned Stake

A state-owned enterprise is a privatized enterprise in which the state has significant control, and which is owned by the state to develop the national economy. The state-owned stake is significantly positively $(+)$ correlated with earnings management $[60,62,64]$ and is defined as the percentage of all issued shares held by the state.

(4) Foreign Ownership Stake

The foreign ownership stake is an effective mechanism for complementing the ownership structure by preventing managers from maximizing management activities that lack value [86]. Foreign investors monitor managers' performance to reduce proxy costs and maintain their profits. The foreign ownership stake is the percentage of all issued shares held by foreign investors.

Control Variables

\section{(1) Company Size (SIZE)}

Previous studies identified a positive correlation between company size and earnings management [37,77]. Lobo and Zhou [87] found that large enterprises are more likely to manipulate profits based on their complex operations. Conversely, other prior studies showed that large enterprises are less likely to adjust their profits because of close monitoring by analysts and investors $[40,88]$. In this study, company size is calculated by taking the natural logarithm of total assets.

\section{(2) Leverage Ratio (LEV)}

Companies with higher leverage ratios are more likely to adjust their profits to meet the requirements of debt contracts $[8,89]$. Managers often adjust their invoices to increase profits to ease lending conditions and allow the company to sign debt contracts. Park [35] documented a negative correlation between leverage ratios and earnings management. We calculated the leverage ratio by dividing total debt by total assets.

(3) Return on Assets (ROA)

The main objective of earnings management is to distort a company's financial statement to achieve a desired level of accounting profits and to deceive investors with misleading information. Kasznik [90] showed a positive correlation between the return on assets and discretionary accruals. The return on assets is calculated by dividing net income by total assets.

(4) Market-to-Book Ratio (MB)

Companies in growth industries raise their profits to avoid falling share prices due to deficits, and, thus, we expected a negative correlation between the market-to-book ratio and earnings management [91]. The market-to-book ratio is calculated as the sum of total liabilities and the market value of equity divided by total assets.

(5) Sales Growth (SG) and Company Age (AGE)

The sales growth rate is calculated by subtracting one from the ratio of current period sales to the previous period sales. Company age is calculated as the natural log of the difference between the current fiscal year and the year of establishment. 
(6) Accounting Audit Company Size $(A U)$

Previous studies used auditing company size as a measure of audit quality. DeAngelo [92] found a positive correlation between accounting audit company size and audit quality. To maintain their reputations, large enterprises need to offer higher quality audit services than what small enterprises offer. Thus, several previous studies showed a negative correlation between the use of Big 4 auditors and profit-adjusting behavior [8,93]. In our empirical analysis, we used a dummy variable that equaled one if the auditor was a member of the Big 4 and zero otherwise.

Table 1 summarizes the measurements of the major variables.

Table 1. Definitions of major variables.

\begin{tabular}{|c|c|}
\hline Variables & Explanation \\
\hline Dependent Variables & Absolute value of discretionary accruals \\
\hline \multicolumn{2}{|l|}{$D A$} \\
\hline \multicolumn{2}{|l|}{ Independent Variables } \\
\hline $\mathrm{CO}$ & $\begin{array}{l}\text { Controlling interest: the percentage of all issued shares } \\
\text { held by controlling shareholders }\end{array}$ \\
\hline MO & $\begin{array}{l}\text { Management ownership stake: the percentage of all issued } \\
\text { shares held by owner-managers }\end{array}$ \\
\hline SO & $\begin{array}{l}\text { State-owned stake: the percentage of all issued shares held } \\
\text { by the state }\end{array}$ \\
\hline FO & $\begin{array}{l}\text { Foreign ownership stake: the percentage of all issued } \\
\text { shares held by foreign investors }\end{array}$ \\
\hline \multicolumn{2}{|l|}{ Control Variables } \\
\hline SIZE & Company size: the natural logarithm of total assets \\
\hline LEV & Leverage ratio: total debt divided by total assets \\
\hline ROA & Return on assets: net income divided by total assets \\
\hline MB & $\begin{array}{l}\text { Market-to-book ratio: the sum of total liabilities and the } \\
\text { market value of equity divided by total assets }\end{array}$ \\
\hline SG & $\begin{array}{l}\text { Sales growth rate, calculated by subtracting one from the } \\
\text { ratio of current period sales to prior period sales }\end{array}$ \\
\hline AGE & $\begin{array}{l}\text { Company age: the natural log of the difference between the } \\
\text { current fiscal year and the year of establishment }\end{array}$ \\
\hline $\mathrm{AU}$ & $\begin{array}{l}\text { A dummy variable equal to one if the auditor is a member } \\
\text { of the Big } 4 \text { and zero otherwise }\end{array}$ \\
\hline
\end{tabular}

\subsection{Models}

We established the following models to identify the effect of changes in the ownership structure on earnings management.

$$
\begin{aligned}
D A_{i t}= & \beta_{0}+\beta_{1} C O_{i t}+\beta_{2} M O_{i t}+\beta_{3} S O_{i t}+\beta_{4} F O_{i t}+\beta_{5} S I Z E_{i t}+\beta_{6} L E V_{i t-1} \\
& +\beta_{7} R O A_{i t-1}+\beta_{8} M B_{i t-1}+\beta_{9} S G_{i t-1}+\beta_{10} A G E_{i t-1}+\beta_{11} A U_{i t}+\varepsilon_{i t}
\end{aligned}
$$

Here,

$\mathrm{CO}_{i t}$ : Controlling shareholders' stake;

$M O_{i t}$ : Management ownership stake;

$S O_{i t}$ : State-owned stake;

$F O_{i t}$ : Foreign ownership stake;

$S I Z E_{i t}$ : Company size; 
$L E V_{i t-1}$ : Leverage ratio;

$R O A_{i t-1}:$ Return on assets;

$M B_{i t-1}$ : Market-to-book ratio;

$S G_{i t-1}$ : Sales growth;

$A G E_{i t-1}$ : Company age;

$A U_{i t}$ : Accounting audit company size (dummy variable equal to one if the auditor is a member of the Big 4 and zero otherwise).

We applied the ordinary least squares (OLS) and Fama-MacBeth regression estimation methods to reduce the standard errors of the estimation.

\section{Empirical Analysis}

\subsection{Descriptive Statistics and Correlations}

\subsubsection{Descriptive Statistics}

Table 2 reports the descriptive statistics for each variable.

Table 2. Descriptive statistics for the major variables.

\begin{tabular}{cccccccccc}
\hline Variables & Average & $\begin{array}{c}\text { Standard } \\
\text { Deviation }\end{array}$ & $\begin{array}{c}\text { Minimum } \\
\text { Value }\end{array}$ & $\begin{array}{c}\text { 5th } \\
\text { Pctl. }\end{array}$ & $\begin{array}{c}\text { 25th } \\
\text { Pctl. }\end{array}$ & Median & $\begin{array}{c}\text { 75th } \\
\text { Pctl. }\end{array}$ & $\begin{array}{c}\text { 95th } \\
\text { Pctl. }\end{array}$ & $\begin{array}{c}\text { Maximum } \\
\text { Value }\end{array}$ \\
\hline$C O$ & 0.4979 & 0.2163 & 0.0000 & 0.0836 & 0.3588 & 0.5192 & 0.6477 & 0.8252 & 0.9925 \\
\hline$M O$ & 0.1122 & 0.1460 & 0.0000 & 0.0002 & 0.0080 & 0.0492 & 0.1673 & 0.4259 & 0.9352 \\
\hline$S O$ & 0.2120 & 0.2511 & 0.0000 & 0.0000 & 0.0000 & 0.0000 & 0.4976 & 0.6500 & 0.8444 \\
\hline$F O$ & 0.1105 & 0.1383 & 0.0000 & 0.0002 & 0.0087 & 0.0503 & 0.1613 & 0.4750 & 0.6462 \\
\hline$A \_D A$ & 0.0272 & 0.1400 & -0.5833 & -0.1785 & -0.0405 & 0.0203 & 0.0882 & 0.2453 & 1.0377 \\
\hline$D A$ & 0.0963 & 0.1052 & 0.0001 & 0.0050 & 0.0282 & 0.0673 & 0.1235 & 0.2950 & 1.0377 \\
\hline$S I Z E$ & 27.1365 & 1.5230 & 23.3304 & 24.6230 & 26.1182 & 27.0836 & 28.1356 & 29.8113 & 32.9960 \\
\hline$L E V$ & 0.5052 & 0.2186 & 0.0020 & 0.1246 & 0.3336 & 0.5307 & 0.6798 & 0.8273 & 0.9706 \\
\hline$R O A$ & 0.0536 & 0.0848 & -1.5874 & -0.0219 & 0.0128 & 0.0418 & 0.0875 & 0.1798 & 0.7837 \\
\hline$M B$ & 1.0146 & 0.4479 & 0.1962 & 0.5862 & 0.8008 & 0.9104 & 1.0900 & 1.8036 & 6.4425 \\
\hline$S G$ & 1.4322 & 43.5537 & -1.0392 & -0.4103 & -0.0773 & 0.0706 & 0.2088 & 0.9798 & 2038.0397 \\
\hline$A G E$ & 3.0652 & 0.5747 & 1.6094 & 2.0794 & 2.6391 & 3.0910 & 3.5553 & 3.9890 & 4.4998 \\
\hline
\end{tabular}

The average value of the controlling shareholders' stake $(\mathrm{CO})$ indicates that controlling shareholders hold around $49.79 \%$ of the shares issued by Vietnamese companies. The standard deviation of $C O$ is $21.63 \%$, which indicates that this variable exhibits sufficient variation in the sample.

The descriptive statistics for $\mathrm{CO}$ also show that the sample included a company whose controlling shareholders' stake did not exceed $5 \%$. This result suggests the importance of restricting investors from holding large stakes because investors can recognize the influence of managers' profit-adjusting behavior.

The average value of the management ownership stake was $11.22 \%$, and the minimum value was $0 \%$, suggesting that the sample included some companies whose managers did not own shares.

The averages of the state-owned stake (SO) and the foreign ownership stake $(F O)$ were $21.20 \%$ and $11.05 \%$, respectively.

The absolute value of discretionary accruals $(D A)$ and discretionary accruals $\left(A \_D A\right)$ were well distributed, and the sample exhibited sufficient variation. Emerging markets like Vietnam provide opportunities for managers to manipulate financial statements. The average value of $D A$ was $9.63 \%$, 
the standard deviation was $10.52 \%$, the minimum was $0.01 \%$, and the maximum was $103.77 \%$, indicating that the degree of profit-adjusting behavior varied greatly across companies.

\subsubsection{Correlations between Variables}

We used Pearson correlations to study the correlations between variables. Table 3 reports the Pearson correlations among the main variables.

The correlations of the absolute value of discretionary accruals $(D A)$ and discretionary accruals $\left(A \_D A\right)$ with the controlling shareholders' stake $(C O)$ were -0.05038 and -0.09395 , respectively, indicating significantly negative (-) correlations. Thus, an increase in the controlling shareholders' stake prevents profit-adjusting behavior.

The correlation between the management ownership stake $(M O)$ and the absolute value of discretionary accruals $(D A)$ was low, with a value of 0.03565 .

The correlation between the state-owned stake $(S O)$ and discretionary accruals $\left(A \_D A\right)$ was -0.09850 , and that between the state-owned stake $(S O)$ and the absolute value of discretionary accruals $(D A)$ was -0.10879 , both of which are negative $(-)$ and significant at the $1 \%$ level. This result contradicts the idea that the correlation between the state-owned stake and earnings management is positive.

A higher foreign ownership stake $(F O)$ is associated with a slightly lower absolute value of discretionary accruals $(D A)$ because the correlation between the two variables is negative $(-)$ and significant at below the $1 \%$ level. This result is in line with our estimation.

Although the correlations between discretionary accruals $\left(A \_D A\right)$ and most control variables, including company size (SIZE), the return on assets $(R O A)$, and the market-to-book ratio $(M B)$, were positive $(+)$, that between discretionary accruals $\left(A \_D A\right)$ and the leverage ratio $(L E V)$ was negative (-).

In contrast, the correlation between the absolute value of discretionary accruals $(D A)$ and most control variables, including company size (SIZE) and company age (AGE), was negative (-). However, that between the absolute value of discretionary accruals $(D A)$ and sales growth $(S G)$ was positive $(+)$.

The correlation between accounting audit company size $(A U)$ and both the absolute value of discretionary accruals $(D A)$ and discretionary accruals $\left(A \_D A\right)$ was negative $(-)$ because enhanced audits increase transparency, resulting in reduced discretionary accruals.

\subsection{Regression Analysis Results for Earnings Management}

Table 4 shows that for Model 1 in Panel A, which shows the OLS regressions, the controlling shareholders' stake (CO) has a significantly negative (-) effect at the $5 \%$ level. Thus, controlling shareholders holding more than $5 \%$ stake in a company have a negative relationship with earnings management. This result is in line with hypothesis 1 . The higher the concentration of stocks is, the lower earnings management is. Our results are consistent with those of Ali et al. [8], Iturriaga and Hoffmann [36], Alves [10], and Roodposhti and Chashmi [37], who showed that controlling shareholders play an important role in monitoring profit-adjusting behavior and proxy costs.

The management ownership stake has a statistically insignificant effect, with a regression coefficient of -0.01235 . This result shows that managers' ownership has absolutely no effect on profit-adjusting behavior. In other words, we found no evidence that a higher management ownership stake worsens profit-adjusting behavior, and, thus, hypothesis 2 was rejected. This result seems reasonable considering the inconsistent views of previous literatures on the relationship between management ownership stake and earnings management. Ali et al. [8], Meckling [33], and Warfield et al. [38] found negative relationship between management ownership stake and earnings management. On the other hand, Morck et al. [52] and Fan and Wong [53] suggested positive relationship between management ownership and financial manipulation. 
Table 3. Correlations between variables.

\begin{tabular}{|c|c|c|c|c|c|c|c|c|c|c|c|c|c|}
\hline Variable & $\mathrm{CO}$ & MO & SO & $F O$ & $A \_D A$ & $D A$ & SIZE & $L E V$ & $R O A$ & $M B$ & $S G$ & $A G E$ & $A U$ \\
\hline $\mathrm{CO}$ & 1 & & & & & & & & & & & & \\
\hline$M O$ & $\begin{array}{c}-0.07746 \\
{[0.0002]}\end{array}$ & 1 & & & & & & & & & & & \\
\hline SO & $\begin{array}{c}0.44212 \\
{[<0.0001]}\end{array}$ & $\begin{array}{l}-0.42469 \\
{[<0.0001]}\end{array}$ & 1 & & & & & & & & & & \\
\hline$F O$ & $\begin{array}{l}0.02259 \\
{[0.2705]}\end{array}$ & $\begin{array}{c}-0.04417 \\
{[0.0311]}\end{array}$ & $\begin{array}{l}-0.12704 \\
{[<0.0001]}\end{array}$ & 1 & & & & & & & & & \\
\hline$A \_D A$ & $\begin{array}{c}-0.05038 \\
{[0.0139]}\end{array}$ & $\begin{array}{l}0.02186 \\
{[0.2862]}\end{array}$ & $\begin{array}{l}-0.09850 \\
{[<0.0001]}\end{array}$ & $\begin{array}{l}0.02894 \\
{[0.1580]}\end{array}$ & 1 & & & & & & & & \\
\hline$D A$ & $\begin{array}{c}-0.0939 \\
{[<0.0001]}\end{array}$ & $\begin{array}{l}0.03565 \\
{[0.0819]}\end{array}$ & $\begin{array}{l}-0.10879 \\
{[<0.0001]}\end{array}$ & $\begin{array}{c}-0.06241 \\
{[0.0023]}\end{array}$ & $\begin{array}{c}0.36209 \\
{[<0.0001]}\end{array}$ & 1 & & & & & & & \\
\hline SIZE & $\begin{array}{c}0.04489 \\
{[0.0285]}\end{array}$ & $\begin{array}{c}-0.02120 \\
{[0.3011]}\end{array}$ & $\begin{array}{l}0.01522 \\
{[0.4577]}\end{array}$ & $\begin{array}{c}0.27722 \\
{[<0.0001]}\end{array}$ & $\begin{array}{c}0.03874 \\
{[0.0587]}\end{array}$ & $\begin{array}{c}-0.07644 \\
{[0.0002]}\end{array}$ & 1 & & & & & & \\
\hline LEV & $\begin{array}{l}0.00836 \\
{[0.6835]}\end{array}$ & $\begin{array}{c}0.10656 \\
{[<0.0001]}\end{array}$ & $\begin{array}{c}0.02428 \\
{[0.2361]}\end{array}$ & $\begin{array}{l}-0.26267 \\
{[<0.0001]}\end{array}$ & $\begin{array}{c}-0.04097 \\
{[0.0455]}\end{array}$ & $\begin{array}{c}0.00521 \\
{[0.7995]}\end{array}$ & $\begin{array}{c}0.33045 \\
{[<0.0001]}\end{array}$ & 1 & & & & & \\
\hline$R O A$ & $\begin{array}{c}0.10798 \\
{[<0.0001]}\end{array}$ & $\begin{array}{c}-0.07737 \\
{[0.0002]}\end{array}$ & $\begin{array}{c}0.08183 \\
{[<0.0001]}\end{array}$ & $\begin{array}{c}0.22786 \\
{[<0.0001]}\end{array}$ & $\begin{array}{c}0.08656 \\
{[<0.0001]}\end{array}$ & $\begin{array}{c}0.01107 \\
{[0.5893]}\end{array}$ & $\begin{array}{c}-0.01852 \\
{[0.3663]}\end{array}$ & $\begin{array}{l}-0.36804 \\
{[<0.0001]}\end{array}$ & 1 & & & & \\
\hline$M B$ & $\begin{array}{c}0.17336 \\
{[<0.0001]}\end{array}$ & $\begin{array}{c}-0.05844 \\
{[0.0043]}\end{array}$ & $\begin{array}{l}0.01283 \\
{[0.5314]}\end{array}$ & $\begin{array}{c}0.24282 \\
{[<0.0001]}\end{array}$ & $\begin{array}{c}0.05791 \\
{[0.0047]}\end{array}$ & $\begin{array}{c}-0.00100 \\
{[0.9612]}\end{array}$ & $\begin{array}{c}0.12618 \\
{[<0.0001]}\end{array}$ & $\begin{array}{l}-0.14562 \\
{[<0.0001]}\end{array}$ & $\begin{array}{c}0.48232 \\
{[<0.0001]}\end{array}$ & 1 & & & \\
\hline$S G$ & $\begin{array}{c}-0.04842 \\
{[0.0181]}\end{array}$ & $\begin{array}{c}-0.01116 \\
{[0.5862]}\end{array}$ & $\begin{array}{c}-0.02607 \\
{[0.2034]}\end{array}$ & $\begin{array}{c}-0.01732 \\
{[0.3981]}\end{array}$ & $\begin{array}{c}-0.02657 \\
{[0.1949]}\end{array}$ & $\begin{array}{l}0.03813 \\
{[0.0628]}\end{array}$ & $\begin{array}{c}-0.00527 \\
{[0.7970]}\end{array}$ & $\begin{array}{l}0.01624 \\
{[0.4283]}\end{array}$ & $\begin{array}{c}-0.02077 \\
{[0.3108]}\end{array}$ & $\begin{array}{c}-0.01547 \\
{[0.4506]}\end{array}$ & 1 & & \\
\hline$A G E$ & $\begin{array}{c}0.12201 \\
{[<0.0001]}\end{array}$ & $\begin{array}{c}-0.04091 \\
{[0.0459]}\end{array}$ & $\begin{array}{c}0.15131 \\
{[<0.0001]}\end{array}$ & $\begin{array}{c}-0.02818 \\
{[0.1692]}\end{array}$ & $\begin{array}{l}0.01795 \\
{[0.3812]}\end{array}$ & $\begin{array}{c}-0.04957 \\
{[0.0155]}\end{array}$ & $\begin{array}{l}0.01664 \\
{[0.4170]}\end{array}$ & $\begin{array}{l}0.07749 \\
{[0.0002]}\end{array}$ & $\begin{array}{c}0.10809 \\
{[<0.0001]}\end{array}$ & $\begin{array}{c}0.15296 \\
{[<0.0001]}\end{array}$ & $\begin{array}{c}-0.03362 \\
{[0.1009]}\end{array}$ & 1 & \\
\hline$A U$ & $\begin{array}{c}0.13701 \\
{[<0.0001]}\end{array}$ & $\begin{array}{l}-0.117040 \\
{[<0.0001]}\end{array}$ & $\begin{array}{c}-0.00048 \\
{[0.9812]}\end{array}$ & $\begin{array}{c}0.33556 \\
{[<0.0001]}\end{array}$ & $\begin{array}{c}-0.03433 \\
{[0.0940]}\end{array}$ & $\begin{array}{l}-0.09065 \\
{[<0.0001]}\end{array}$ & $\begin{array}{c}0.48009 \\
{[<0.0001]}\end{array}$ & $\begin{array}{l}0.01817 \\
{[0.3753]}\end{array}$ & $\begin{array}{c}0.01857 \\
{[0.3651]}\end{array}$ & $\begin{array}{c}0.14481 \\
{[<0.0001]}\end{array}$ & $\begin{array}{c}-0.01413 \\
{[0.4907]}\end{array}$ & $\begin{array}{l}0.00376 \\
{[0.8545]}\end{array}$ & 1 \\
\hline
\end{tabular}


Table 4. Results of regressing earnings management on different ownership stakes.

\begin{tabular}{|c|c|c|}
\hline & & $D A$ \\
\hline & Model 1 & Model 2 \\
\hline \multicolumn{3}{|c|}{ Panel A: OLS Regressions } \\
\hline Intercept & $0.12458^{* * *}(20.63)$ & $0.21853^{* * *}(4.64)$ \\
\hline $\mathrm{CO}$ & $-0.02311^{* *}(-2.07)$ & $-0.02068^{* *}(-1.80)$ \\
\hline $\mathrm{MO}$ & $-0.01116(-0.68)$ & $-0.01499(-0.90)$ \\
\hline $\mathrm{SO}$ & $-0.04356^{* * *}(-4.05)$ & $-0.04287^{* * *}(-3.93)$ \\
\hline FO & $-0.05723^{* * *}(-3.63)$ & $-0.03933^{* *}(-2.16)$ \\
\hline SIZE & & $-0.00325 *(-1.81)$ \\
\hline LEV & & $0.01638(1.36)$ \\
\hline $\mathrm{ROA}$ & & $0.04941(1.60)$ \\
\hline MB & & $0.00582(1.03)$ \\
\hline SG & & $0.00007(1.51)$ \\
\hline AGE & & $-0.00731 * *(-1.91)$ \\
\hline AU & & $-0.01251 * *(-2.12)$ \\
\hline \multirow[t]{3}{*}{ Adj. R-squared } & 0.0183 & 0.0251 \\
\hline & Model 1 & Model 2 \\
\hline & \multicolumn{2}{|c|}{ Panel B: Fama-MacBeth Regressions } \\
\hline Intercept & $0.12439^{* * *}(11.21)$ & $0.24241^{* * *}(13.17)$ \\
\hline $\mathrm{CO}$ & $-0.02191(-1.08)$ & $-0.01858(-0.93)$ \\
\hline $\mathrm{MO}$ & $-0.01235(-0.97)$ & $-0.01651(-1.42)$ \\
\hline SO & $-0.04239^{* * *}(-11.64)$ & $-0.04043^{* * *}(-11.44)$ \\
\hline FO & $-0.0618^{* * *}(-6.92)$ & $-0.04287^{* * *}(-4.14)$ \\
\hline SIZE & & $-0.00404^{* * *}(-4.17)$ \\
\hline LEV & & $0.01814 * *(3.66)$ \\
\hline ROA & & $0.05031^{* * *}(5.60)$ \\
\hline MB & & $0.00475^{* * *}(3.98)$ \\
\hline SG & & $0.00094(1.53)$ \\
\hline AGE & & $-0.00859^{* * *}(-8.20)$ \\
\hline AU & & $-0.01111^{* * *}(-4.05)$ \\
\hline Adj. R-squared & 0.0202 & 0.0251 \\
\hline
\end{tabular}

The regression coefficient of the state-owned stake $(\mathrm{SO})$ was negative (-); the higher the state-owned stake was, the lower discretionary accruals were. This result was not in line with our hypothesis and showed that the state-owned stake plays an important role in the Vietnamese market. Although previous studies showed inconsistent views, our result goes in line with the views of Chung et al. [66], who showed that state-owned stake negatively impacts earnings management.

The effect of the foreign ownership stake was statistically significant at the $1 \%$ level, with a regression coefficient of -0.0618 . This result is in line with hypothesis 4 . The higher the foreign ownership stake, the lower the earnings management is. Our results are consistent with those of Chung et al. [16], Ahn et al. [74], and Firth et al. [67], who showed negative relationship between foreign ownership stake and earnings management.

In Model 2, the correlations between the absolute value of discretionary accruals $(D A)$ and the independent variables, including the controlling shareholders' stake $(C O)$, state-owned stake $(S O)$, and foreign ownership stake (FO), are negative (-). Company size (SIZE), company age (AGE), and accounting audit company size $(A U)$ had significant negative $(-)$ relationships with earnings management, whereas the other control variables had no statistical significance and did not affect earnings management.

Panel B of Table 4 provides the results for the Fama-MacBeth regressions. Model 1 shows that the controlling shareholders' stake $(C O)$ and the absolute value of discretionary accruals $(D A)$ do not have a significant relationship, which is different from the result in Panel A. 
According to Model 2, the state-owned stake (SO) and the foreign ownership stake (FO) are negatively (-) correlated with the absolute value of discretionary accruals $(D A)$. The control variables, such as company size (SIZE), company age $(A G E)$, and accounting audit company size $(A U)$, had significant negative $(-)$ relationships with earnings management at the $1 \%$ level. The return on assets $(R O A)$, market-to-book ratio $(M B)$, and leverage ratio $(L E V)$ were positively $(+)$ correlated with the absolute value of discretionary accruals $(D A)$.

In particular, the results in both panels show that company age $(A G E)$ and accounting audit company size $(A U)$ are negatively and significantly associated with the absolute value of discretionary accruals $(D A)$. Firms with more history and larger audit firms tend to be more transparent and, thus, are less likely to conduct earnings management because they may provide more reliable information to the market.

We further elaborated on our results by analyzing subsamples of companies that have discretionary accruals with both negative and positive values.

According to Model 3 in Panel A of Table 5, which shows the results for the OLS regressions, the foreign ownership stake $(F O)$ has a positive $(+)$ effect at the $1 \%$ significance level.

According to Model 4, all of the independent variables are correlated with both negative (-) and positive $(+)$ discretionary accruals $\left(A \_D A\right)$, but these correlations are not significant. Company size $(S I Z E)$ affects discretionary accruals $\left(A \_D A\right)$ with both negative $(-)$ and positive $(+)$ values at the $1 \%$ significance level. The leverage ratio $(L E V)$ is negatively $(-)$ correlated with discretionary accruals $\left(A \_D A\right)$ with negative $(-)$ values.

According to Model 5, the controlling shareholders' stake (CO), the state-owned stake $(S O)$, and the foreign ownership stake $(F O)$ have regression coefficients of $-0.03066,-0.06721$, and -0.06409 , respectively, implying significant negative (-) effects.

According to Model 6, discretionary accruals $\left(A \_D A\right)$ with positive values are negatively $(-)$ correlated with the controlling shareholders' stake (CO), state-owned stake (SO), and foreign ownership stake (FO), implying similar results to those of Model 5. We found no correlations between the control variables and discretionary accruals $\left(A \_D A\right)$ with positive values.

Panel B shows the results for Fama-MacBeth regressions. The results for Models 3 and 4 are consistent with those in Panel A.

Model 5 indicates that there is no correlation between the controlling shareholders' stake $(C O)$ and discretionary accruals $\left(A \_D A\right)$ with positive values. However, the regression coefficient of the management ownership stake $(M O)$ is -0.03123 , which is statistically significant.

According to Model 6, discretionary accruals $\left(A \_D A\right)$ with positive values are negatively correlated with the state-owned stake (SO) and the foreign ownership stake (FO). However, we found no correlation between discretionary accruals $\left(A \_D A\right)$ with positive values and the controlling ownership stake $(C O)$ or the management ownership stake $(M O)$. The return on assets $(R O A)$ and the market-to-book ratio $(M B)$ had positive $(+)$ effects at the $5 \%$ significance level, and company age (AGE) and accounting audit company size $(A U)$ had statistically significant negative (-) effects.

We assumed that a larger scale mitigates the relationship between ownership structure and discretionary accruals. Table 6 shows this relationship for companies of different sizes.

For large firms, discretionary accruals $\left(A \_D A\right)$ were negatively $(-)$ correlated with the state-owned (SO) and foreign ownership stakes (FO) at the 5\% level. In addition, the correlation between the controlling shareholders' stake $(C O)$ and discretionary accruals $(D A)$ was negative $(-)$. The return on assets $(R O A)$ had a negative $(-)$ effect at the $5 \%$ significance level.

Similar to the results for large firms, discretionary accruals $\left(A \_D A\right)$ were negatively $(-)$ correlated with the state-owned $(S O)$ and foreign ownership stakes $(F O)$ for small firms. The correlation between the management ownership stake $(M O)$ and discretionary accruals $(D A)$ was negative $(-)$. 
Table 5. Results of regressing discretionary accruals on ownership stakes for companies with positive and negative discretionary accruals.

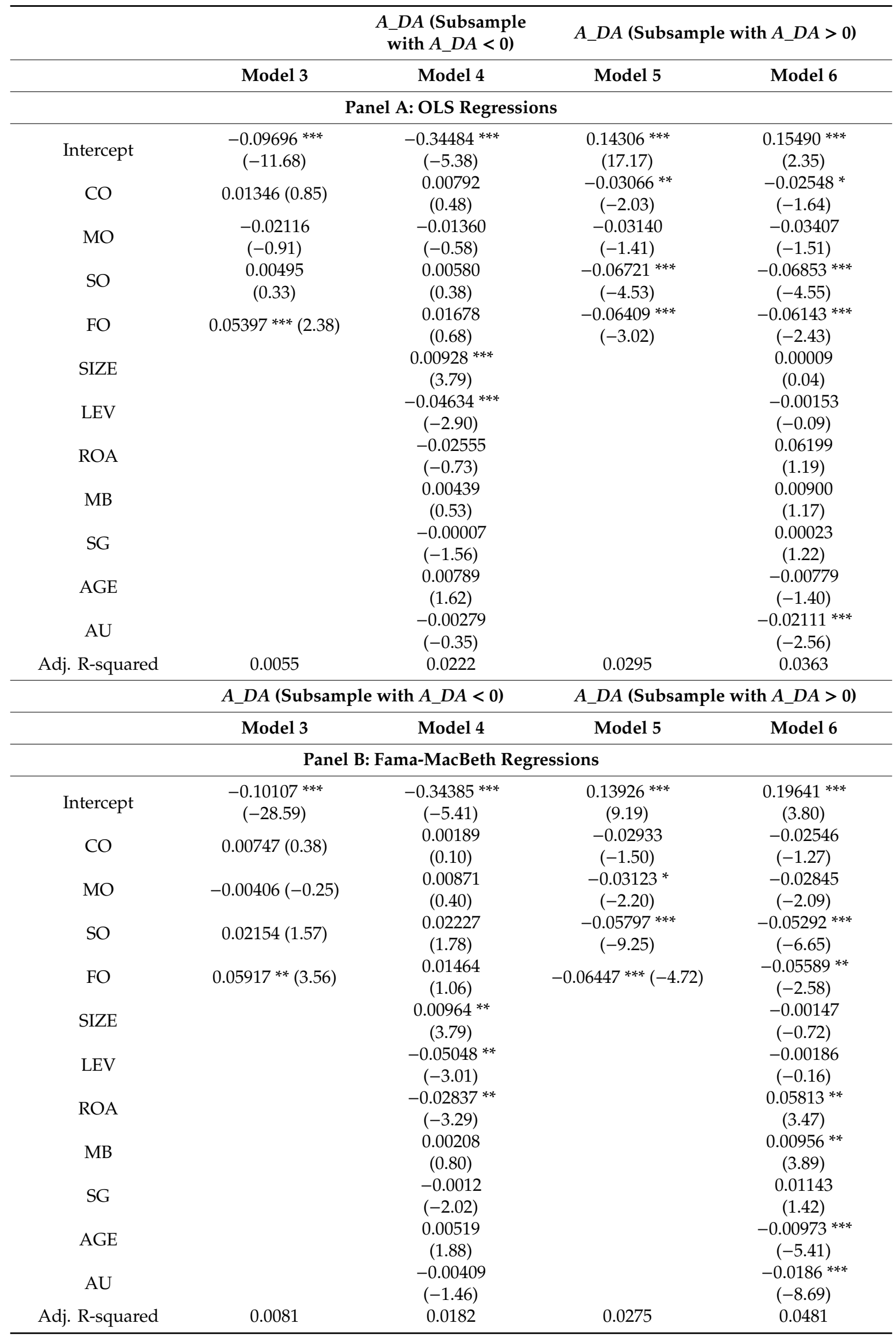


Table 6. Effect of company size on the relationship between ownership structures and discretionary accruals.

\begin{tabular}{ccc}
\hline & & $D A$ \\
\hline & Large Firms & Small Firms \\
\hline Intercept & $0.1515^{* * *}(9.69)$ & $0.1374^{* * *}(15.17)$ \\
CO & $-0.0211^{* *}(-3.70)$ & $-0.0201(-0.87)$ \\
MO & $-0.0037(-0.11)$ & $-0.0210^{* * *}(-2.91)$ \\
SO & $-0.0573^{* *}(-4.31)$ & $-0.0349^{* * *}(-12.71)$ \\
FO & $-0.0879^{* *}(-3.99)$ & $-0.0396^{*}(-2.28)$ \\
LEV & $0.0068(0.77)$ & $0.0075(1.07)$ \\
ROA & $0.1254^{* *}(4.26)$ & $0.0326(1.44)$ \\
MB & $0.0063(1.53)$ & $0.0030(0.85)$ \\
SG & $0.0076(1.80)$ & $0.0035(1.87)$ \\
AGE & $-0.0120^{* *}(-3.32)$ & $-0.0071^{* * *}(-5.37)$ \\
AU & $-0.0171^{* * *}(-4.22)$ & $-0.0126^{* * *}(-6.26)$ \\
Obs. & 431 & 1951 \\
Adj. R-squared & 0.0469 & 0.0115 \\
\hline Note: Stars denote statistical significance: ${ }^{*} p<0.10, * * p<0.05, * * *<0.01$.
\end{tabular}

In both cases, company age $(A G E)$ and accounting audit company size $(A U)$ had statistically significantly negative $(-)$ effects.

Our results showed that the negative relationship between independent variables and discretionary accruals indicates that the ownership structure weakens profit-adjusting behavior. Table 6 shows that company size and discretionary accruals are significantly related.

Additional Analyses on the Controlling Shareholders' Stake

We examined our results by separately analyzing the subsample of companies with controlling shareholders' stakes of $50 \%$ or more and the subsample of companies with controlling shareholders' stakes of less than $50 \%$. Table 7 reports the results.

Table 7. Correlation between earnings management and ownership structure for subsamples of companies.

\begin{tabular}{ccc}
\hline & \multicolumn{1}{c}{$\boldsymbol{C} \boldsymbol{D}<\mathbf{5 0} \%$} & $\boldsymbol{C O}>\mathbf{5 0} \%$ \\
\hline Intercept & $0.1939^{* *}(4.24)$ & $0.2670^{* * *}(25.50)$ \\
MO & $-0.0228(-0.94)$ & $-0.0231(-1.38)$ \\
SO & $-0.0887^{* *}(-3.04)$ & $-0.0309^{* * *}(-6.61)$ \\
FO & $-0.0781^{* * *}(-5.17)$ & $-0.0192^{*}(-2.15)$ \\
SIZE & $-0.0008^{* *-52)}$ & $-0.0071^{* * *}(-17.40)$ \\
LEV & $-0.0225^{* *}(-2.78)$ & $0.0547^{* *}(3.84)$ \\
ROA & $0.0618(1.90)$ & $0.0835^{* *}(2.68)$ \\
MB & $0.0134^{* *}(3.70)$ & $0.0029(0.61)$ \\
SG & $0.0013(1.57)$ & $0.0110^{* *}(2.77)$ \\
AGE & $-0.0170^{* *}(-2.81)$ & $-0.0023(-0.79)$ \\
AU & $-0.0218^{* *}(-3.46)$ & $-0.0038(-1.75)$ \\
Obs. & 980 & 1402 \\
Adj. R-squared & 0.02111 & 0.02261 \\
\hline
\end{tabular}

Note: Stars denote statistical significance: ${ }^{*} p<0.10,{ }^{* *} p<0.05,{ }^{* * *} p<0.01$.

Discretionary accruals $\left(A \_D A\right)$ with positive values were negatively $(-)$ correlated with the state-owned (SO) and foreign ownership stakes $(F O)$, as in the previous results.

However, we found no significant correlations between discretionary accruals $(D A)$ and company age $(A G E)$ or accounting audit company size $(A U)$ for companies that have controlling shareholders' stakes of $50 \%$ or more. 
We, therefore, concluded that an increase in the controlling shareholders' stake does not deter profit-adjusting behavior.

Our analysis results are similar to those of Ding et al. [61], who reported that asset acceptance does not increase when the ownership concentration reaches a certain threshold. They reported that an increase in voting rights leads controlling shareholders to remain active in controlling a company. As expected, the subsample of companies with controlling shareholders' stakes of $50 \%$ or more exhibited a negative correlation between earnings management and the foreign ownership and state-owned stakes, as we found negative (-) coefficients of $F O$ and SO.

\section{Conclusions}

\subsection{Summary}

We analyzed the effect of the ownership structure on earnings management using the financial statements of companies listed on the Ho Chi Minh Stock Exchange and the Hanoi Stock Exchange. We aimed to contribute to improving the quality of financial statements and provide a useful reference for investors, managers, auditors, state-managing institutions, and other relevant stakeholders.

The ownership structure factors in our research model included the controlling shareholders' stake, management ownership stake, state-owned stake, and foreign ownership stake. We verified that the controlling shareholders' stake, state-owned stake, and foreign ownership stake were significantly correlated with earnings management. In addition, six of the seven control variables, namely company size, the leverage ratio, the return on assets, the market-to-book ratio, company age, and accounting audit company size, affected profit-adjusting behavior.

Our analysis results are as follows.

First, the controlling shareholders' stake was negatively correlated with earnings management. The higher the controlling shareholders' stake was, the lower the managers' incentive to adjust profits was. In other words, our result is consistent with the argument that managers can be kept under control by maximizing the controlling shareholders' stake such that there is less opportunity to adjust profits. In Vietnam, controlling shareholders are part of the internal governance mechanisms and monitor managers' decisions. Thus, the quality of the ownership structure moves Vietnam increasingly close to international best practices.

Second, the management ownership stake did not affect earnings management. Shareholders' profits corresponded to managers' profits when managers hold stakes in companies, implying that management ownership does not curb earnings management. In other words, our results do not support our hypothesis because of a lack of expertise or the free rider problem, which generally leads to short-sightedness.

Third, opportunistic earnings management decreased as the state-owned stake increased. Our results did not support our hypothesis that state ownership is the basis for inadequate market discipline and inefficiency in management and causes managers' opportunistic behaviors. The results are consistent with those of Chung et al. [66], Wang and Campbell [63], and Hoang et al. [94]. These surprising results imply that state ownership may have served as a strong external monitor against managers' opportunism. In addition, having the ultimate protection from a country with fixed compensation plans and supporting credit terms may have reduced management pressure to manipulate specific company-related information even during difficult times [66]. In conclusion, the state-owned stake induces higher profits as the economy becomes increasingly market-driven.

Fourth, the foreign ownership stake was negatively correlated with earnings management. Our results are consistent with studies that found that foreign investors limit managers' earnings management by providing useful information on profitability through their superior information and management monitoring capabilities in developing countries. Our findings highlight the importance of foreign shareholders in Vietnamese listed companies when enhancing the quality of profits. Through external monitoring, foreign investors reduce agency costs based on the information asymmetry of the invested firms. 
Fifth, earnings management varied based on company size. Our results are consistent with previous studies, which reported that large enterprises have fewer incentives to perform earnings management because those enterprises provide more information and are supervised by analysts and investors $[40,88]$. According to our additional analyses, although the ownership structure may reduce profit-adjusting behavior, other factors, such as company size, may also affect profit-adjusting behavior. The management ownership stake is an effective monitoring mechanism, especially for small businesses. Our results suggest that small- and medium-sized enterprises should encourage management rights to address weaknesses in their ownership structures.

Sixth, the leverage ratio had a positive effect on earnings management. This result suggests that the more financial leverage a company has, the more likely it is to engage in profit-adjusting behavior.

Seventh, the return on assets was positively correlated with earnings management. Our results are consistent with a previous study that reported that highly profitable companies are always prepared for earnings management [76].

Eighth, the higher the market-to-book ratio was, the higher earnings management was. We found no correlation between the sales growth rate and profit-adjusting behavior.

Ninth, company age and earnings management were negatively correlated. In other words, the higher the company age was, the lower earnings management was.

Lastly, having a Big 4 auditing firm as an auditor, which reflects the size of the auditor, had an effect on the level of earnings management. This finding indicates that the auditor's reputation and the manager's choice of accounting method are related and that a well-known auditor (i.e., a member of the Big 4) limits managers' ability to adjust profits.

\subsection{Contributions}

Our study contributes to the Vietnamese market by showing that the effect of the corporate ownership structure depends on the type of ownership and that these mechanisms should be studied simultaneously.

Our results show that the Vietnamese government and listed companies should encourage domestic and foreign investment to increase the efficiency of the stock market and should design policies that reduce capital costs. Doing so will improve the nation's economic wealth.

Our study intends to provide insights into existing studies on sustainable ownership structure mechanisms and managers' profit-adjusting behavior. This study will enhance the scope of understanding of the effect of the ownership structure on earnings management, especially in Vietnam, where the legal systems for minority shareholders are weak.

But here lies the limitation of our research. We have shown significant relationship between corporate ownership structure and earnings management, and previous studies showed significant relationship between companies' CSR and SRA practices and their earnings management. However, we did not show the direct two-way effects of ownership structures on firm's unethical behaviors and CSR practices, but rather suggest an indirect insight.

Therefore, we further suggest new directions for research investigating the relationship between earnings management and companies' CSR and SRA practices. It would be interesting to study this relationship within the context of the abovementioned corporate ownership structures in future work.

In addition, our study reports conflicting evidence regarding the difference in the quality of profit-related information provided by state-owned enterprises and private enterprises. We expected our findings to provide important practical implications for policymakers. Additional reforms can enhance transparency in accounting reports and should protect minority shareholders via the legal system, administrative procedures, financial and grand disclosures, and regulatory oversight.

Finally, we recommend that countries accelerate the privatization process in each sector to strategically attract foreign investment and gradually reduce the state's presence as a controlling shareholder. 
Author Contributions: Methodology and data analysis, C.Y.C.; writing-original draft preparation, Y.-E.K.; writing-review and editing, D.C., C.Y.C., Y.J.K. and P.M.S.C. All authors read and approved the final manuscript.

Funding: This work was supported by the research program of Kookmin University in Korea.

Conflicts of Interest: The authors declare no conflict of interest.

\section{References}

1. Healy, P.M.; Wahlen, J.M. A review of the earnings management literature and its implications for standard setting. Account. Horiz. 1999, 13, 365-383. [CrossRef]

2. Roychowdhury, S. Earnings management through real activities manipulation. J. Account. Econ. 2006, 42, 335-370. [CrossRef]

3. Gupta, P.; Sharma, A.M. A study of the impact of corporate governance practices on firm performance in Indian and South Korean companies. Procedia-Soc. Behav. Sci. 2014, 133, 4-11. [CrossRef]

4. Son, P. A study on the relationship between corporate governance and earnings management. J. CEO Manag. Stud. 2008, 11, 159-182.

5. Bae, H.; Kim, K. Effect of corporate governance on accruals earnings management and real earnings management. Account. Inf. Rev. 2012, 30, 115-146.

6. Choi, S.; Kim, K. Corporate control and earnings management. Korean Account. Rev. 2001, 26, $153-178$.

7. Persons, O.S. Corporate governance and non-financial reporting fraud. J. Bus. Econ. Stud. 2006, 12, 27.

8. Ali, S.M.; Salleh, N.M.; Hassan, M.S. Ownership structure and earnings management in Malaysian listed companies: The size effect. Asian J. Bus. Account. 2008, 1, 89-116.

9. Banderlipe, I.I.; McReynald, S. The impact of selected corporate governance variables in mitigating earnings management in the Philippines. DLSU Bus. Econ. Rev. 2009, 19, 17-27. [CrossRef]

10. Alves, S. Ownership structure and earnings management: Evidence from Portugal. Australas. Account. Bus. Financ. J. 2012, 6, 57-74.

11. Barberis, N.; Shleifer, A.; Vishny, R. A model of investor sentiment. J. Financ. Econ. 1998, 49, 307-343. [CrossRef]

12. Smith, E.D. The effect of the separation of ownership from control on accounting policy decisions. Account. Rev. 1976, 51, 707-723.

13. Ghosh, M.; Whalley, J. State owned enterprises, shirking and trade liberalization. Econ. Model. 2008, 25, 1206-1215. [CrossRef]

14. Seasholes, M.S. Smart Foreign Traders in Emerging Markets; Unpublished Harvard Business School Working Paper; Harvard Business School: Boston, MA, USA, 2000.

15. Gillan, S.; Starks, L.T. Corporate governance, corporate ownership, and the role of institutional investors: A global perspective. J. Appl. Financ. 2003, 13, 4-22. [CrossRef]

16. Chung, R.; Ho, S.; Kim, J.B. Ownership structure and the pricing of discretionary accruals in Japan. J. Int. Account. Audit. Tax. 2004, 13, 1-20. [CrossRef]

17. Minh, T.L.; Walker, G. Corporate governance of listed companies in Vietnam. Bond. L. Rev. 2008, 20, I. [CrossRef]

18. $\mathrm{Vu}$, K.B.A.H. Determinants of Voluntary Disclosure for Vietnamese Listed Firms. Ph.D. Thesis, Curtin University, Perth, Australia, 2012.

19. Chaney, P.K.; Faccio, M.; Parsley, D. The quality of accounting information in politically connected firms. J. Account. Econ. 2011, 51, 58-76. [CrossRef]

20. Loc, T.D.; Lanjouw, G.; Lensink, R. The impact of privatization on firm performance in a transition economy: The case of Vietnam 1. Econ. Transit. 2006, 14, 349-389. [CrossRef]

21. Cook, P.; Kirkpatrick, C. Privatization, Enterprise Development and Economic Reform; Edward Elgar Publishing: Cheltenham, UK, 1998.

22. Frederick, W.C. Corporation, Be Good! The Story of Corporate Social Responsibility; Dog Ear Publishing: Indianapolis, IN, USA, 2006.

23. Cuong, D.P.; Tyrone, M.C. Financial performance of privatized state-owned enterprises in Vietnam. J. Int. Bus. Res. 2008, 7, 105-125.

24. Kim, W.S.; Lyn, E.O. Excess market value, market power, and inside ownership structure. Rev. Ind. Org. 1988, 3, 1-25. [CrossRef]

25. Schipper, K. Earnings management. Account. Horiz. 1989, 3, 91.

26. Scott, W. Financial Accounting Theory; USA Prentice Hall, Inc.: Upper Saddle River, NJ, USA, 1997. 
27. Levitt, A. The importance of high quality accounting standards. Am. Account. Assoc. 1998, 12, 79-82.

28. Akers, M.D.; Giacomino, D.E.; Bellovary, J.L. Earnings management and its implications. Account. Fac. Res. Publ. 2007, 77, 64-68.

29. Beneish, M.D. Earnings Management: A Perspective. Manag. Financ. 2001, 27. [CrossRef]

30. Gordon, M.J. Security and investment: Theory and evidence. J. Financ. 1964, 19, 607-618.

31. Chung, C.Y.; Liu, C.; Wang, K.; Zykaj, B.B. Institutional monitoring: Evidence from the F-score. J. Bus. Financ. Account. 2015, 42, 885-914. [CrossRef]

32. Huang, X.S.; Sun, L. Managerial ability and real earnings management. Adv. Account. 2017, 39, 91-104. [CrossRef]

33. Jensen, M.C.; Meckling, W.H. Theory of the firm: Managerial behavior, agency costs, and ownership structure. J. Financ. Econ. 1976, 3, 305-360. [CrossRef]

34. Shleifer, A.; Vishny, R.W. Large shareholders and corporate control. J. Political Econ. 1986, 94, 461-488. [CrossRef]

35. Park, J.I. Corporate governance and earnings management: View from the largest shareholder's holding. Korean Account. Rev. 2003, 28, 135-172.

36. Iturriaga, F.J.L.; Hoffmann, P.S. Earnings management and internal mechanisms of corporate governance: Empirical evidence from Chilean firms. Corp. Ownersh. Control 2005, 3, 17-29. [CrossRef]

37. Roodposhti, F.R.; Chashmi, S.N. The impact of corporate governance mechanisms on earnings management. Afr. J. Bus. Manag. 2011, 5, 4143-4151.

38. Warfield, T.D.; Wild, J.J.; Wild, K.L. Managerial ownership, accounting choices, and informativeness of earnings. J. Account. Econ. 1995, 20, 61-91. [CrossRef]

39. Marrakchi Chtourou, S.; Bédard, J.; Courteau, L. Corporate Governance and Earnings Management. Afr. J. Bus. Manag. 2001, 11, 4143-4151. [CrossRef]

40. Rahman, R.A.; Ali, F.H.M. Board, audit committee, culture and earnings management: Malaysian evidence. Manag. Audit. J. 2006, 21, 783-804. [CrossRef]

41. García-Meca, E.; Sánchez-Ballesta, J.P. Corporate governance and earnings management: A meta-analysis. Corp. Gov. Int. Rev. 2009, 17, 594-610. [CrossRef]

42. Lee, H.; Park, K. A study on earning management of firms by ownership percentage changes of majority shareholders. Stud. Account. Tax. Audit. 2006, 43, 65-92.

43. Dechow, P.M.; Sloan, R.G.; Sweeney, A.P. Causes and consequences of earnings manipulation: An analysis of firms subject to enforcement actions by the SEC. Contemp. Account. Res. 1996, 13, 1-36. [CrossRef]

44. Yafeh, Y.; Yosha, O. Large Shareholders and Banks: Who Monitors and How (Volume 1178); Centre for Economic Policy Research: London, UK, 1995.

45. Jaggi, B.; Tsui, J. Insider trading, earnings management and corporate governance: Empirical evidence based on Hong Kong firms. J. Int. Financ. Manag. Account. 2007, 18, 192-222. [CrossRef]

46. Gillian, S.L.; Martin, J.D. Financial Engineering, Corporate Governance, and the Collapse of Enron; University of Delaware Governance Working Paper No. 2002-001; University of Delaware: Newark, DE, USA, 2002.

47. McConnell, J.J.; Servaes, H. Additional evidence on equity ownership and corporate value. J. Financ. Econ. 1990, 27, 595-612. [CrossRef]

48. Klein, A. Audit committee, board of director characteristics, and earnings management. J. Account. Econ. 2002, 33, 375-400. [CrossRef]

49. Dhaliwal, D.S.; Salamon, G.L.; Smith, E.D. The effect of owner versus management control on the choice of accounting methods. J. Account. Econ. 1982, 4, 41-53. [CrossRef]

50. Ebrahim, A. Earnings management and board activity: An additional evidence. Rev. Account. Financ. 2007, 6, 42-58. [CrossRef]

51. Cho, S.J.; Chung, C.Y.; Young, J. Study on the relationship between CSR and financial performance. Sustainability 2019, 11, 343. [CrossRef]

52. Morck, R.; Shleifer, A.; Vishny, R.W. Management ownership and market valuation: An empirical analysis. J. Financ. Econ. 1988, 20, 293-315. [CrossRef]

53. Fan, J.P.H.; Wong, T.J. Corporate ownership structure and the informativeness of accounting earnings in East Asia. J. Account. Econ. 2002, 33, 401-425. [CrossRef]

54. Wang, X. Mutual empowerment of state and society: Its nature, conditions, mechanisms, and limits. Comp. Politics 1999, 31, 231-249. [CrossRef]

55. Qi, D.; Wu, W.; Zhang, H. Shareholding structure and corporate performance of partially privatized firms: Evidence from listed Chinese companies. Pac.-Basin Financ. J. 2000, 8, 587-610. [CrossRef] 
56. Sun, Q.; Tong, W.H.S. China share issue privatization: The extent of its success. J. Financ. Econ. 2003, 70, 183-222. [CrossRef]

57. Bai, C.E.; Liu, Q.; Song, F.M.; Zhang, J. Corporate governance and market valuation in China. J. Comp. Econ. 2004, 32, 599-616. [CrossRef]

58. Liu, C.; Chung, C.Y.; Sul, H.K.; Wang, K. Does hometown advantage matter? The case of institutional blockholder monitoring on earnings management in Korea. J. Int. Bus. Stud. 2018, 49, 196-221. [CrossRef]

59. Leuz, C.; Nanada, D.; Wysocki, P.D. Earnings management and investor protection: An international comparison. J. Financ. Econ. 2003, 69, 505-527. [CrossRef]

60. Bauwhede, H.V.; Willekens, M.; Gaeremynck, A. Audit firm size, public ownership, and firms' discretionary accruals management. Int. J. Account. 2003, 38, 1-22. [CrossRef]

61. Ding, Y.; Zhang, H.; Zhang, J. Private vs. state ownership and earnings management: Evidence from Chinese listed companies. Corp. Gov. Int. Rev. 2007, 15, 223-238. [CrossRef]

62. Chen, X.; Lee, C.W.J.; Li, J. Government assisted earnings management in China. J. Account. Public Policy 2008, 27, 262-274. [CrossRef]

63. Wang, Y.; Campbell, M. Corporate governance, earnings management, and IFRS: Empirical evidence from Chinese domestically listed companies. Adv. Account. 2012, 28, 189-192. [CrossRef]

64. Ben-Nasr, H.; Boubakri, N.; Cosset, J.C. Earnings quality in privatized firms: The role of state and foreign owners. J. Account. Public Policy 2015, 34, 392-416. [CrossRef]

65. Poli, S. Do ownership structure characteristics affect Italian private companies' propensity to engage in the practices of "earnings minimization" and "earnings change minimization". Int. J. Econ. Financ. 2015, 7, 193-207. [CrossRef]

66. Chung, C.Y.; Jung, S.; Young, J. Do CSR activities increase firm value? Evidence from the Korean market. Sustainability 2018, 10, 3164. [CrossRef]

67. Firth, M.; Fung, P.M.; Rui, O.M. Ownership, two-tier board structure, and the informativeness of earnings-Evidence from China. J. Account. Public Policy 2007, 26, 463-496. [CrossRef]

68. Liu, Q.; Lu, Z. Corporate governance and earnings management in the Chinese listed companies: A tunneling perspective. J. Corp. Financ. 2007, 13, 881-906. [CrossRef]

69. Malatesta, P.H.; DeWenter, K.L. State-owned and privately owned firms: An empirical analysis of profitability, leverage, and labor intensity. Am. Econ. Rev. 2001, 91, 320-334.

70. Fan, J.P.H.; Wong, T.J.; Zhang, T. Politically connected CEOs, corporate governance, and post-IPO performance of China's newly partially privatized firms. J. Financ. Econ. 2007, 84, 330-357. [CrossRef]

71. Choi, D.; Choi, P.M.S.; Choi, J.H.; Chung, C.Y. Corporate governance and corporate social responsibility: Evidence from the role of the largest institutional blockholders in the Korean market. Sustainability 2020, 12, 1680. [CrossRef]

72. Sueyoshi, T.; Goto, M.; Omi, Y. Corporate governance and firm performance: Evidence from Japanese manufacturing industries after the lost decade. Eur. J. Oper. Res. 2010, 203, 724-736. [CrossRef]

73. Jeon, Y. The association between foreign and domestic institutional ownership and earnings quality. Korean Manag. Rev. 2003, 32, 1001-1032.

74. Ahn, Y.Y.; Shin, H.H.; Chang, J.H. The relationship between the foreign investor and information asymmetry. Korean Account. Rev. 2005, 30, 109-131.

75. Kim, H.J.; Yoon, S.S. The impact of corporate governance on earnings management in Korea. Manag. Account. Rev. 2008, 7, 43-59.

76. Dechow, P.M.; Sloan, R.G.; Sweeney, A.P. Detecting earnings management. Account. Rev. 1995, 70, $193-225$.

77. Klai, N.; Omri, A. Corporate governance and financial reporting quality: The case of Tunisian firms. Int. Bus. Res. 2011, 4, 158-166. [CrossRef]

78. Khanna, T.; Palepu, K. Emerging Market Business Groups, Foreign Intermediaries, and Corporate Governance. In Concentrated Corporate Ownership; University of Chicago Press: Chicago, IL, USA, 2000; pp. 265-294.

79. Kim, W.S.; Park, K.; Lee, S.H. Corporate social responsibility, ownership structure, and firm value: Evidence from Korea. Sustainability 2018, 10, 2497. [CrossRef]

80. Salvioni, D.M.; Gennari, F. Corporate governance, ownership and sustainability. Corp. Ownersh. Control 2016, 13, 606-614. [CrossRef]

81. Hummel, K.; Ising, P. Earnings Management_Does Corporate Sustainability Performance Matter? UZH Business Working Paper No. 358; University of Zurich: Zurich, Switzerland, 2015. 
82. Grimaldi, F.; Caragnano, A.; Zito, M.; Mariani, M. Sustainability engagement and earnings management: The Italian context. Sustainability 2020, 12, 4881. [CrossRef]

83. Chou, D.W.; Gombola, M.; Liu, F.Y. Earnings management and stock performance of reverse leveraged buyouts. J. Financ. Quant. Anal. 2006, 41, 407-438. [CrossRef]

84. Kothari, S.P.; Leone, A.J.; Wasley, C.E. Performance matched discretionary accrual measures. J. Account. Econ. 2005, 39, 163-197. [CrossRef]

85. Zeckhauser, R.J.; Pound, J. Are Large Shareholders Effective Monitors? An Investigation of Share Ownership and Corporate Performance. In Asymmetric Information, Corporate Finance, and Investment; University of Chicago Press: Chicago, IL, USA, 1990; pp. 149-180.

86. Dahlquist, M.; Robertsson, G. Direct foreign ownership, institutional investors, and firm characteristics. J. Financ. Econ. 2001, 59, 413-440. [CrossRef]

87. Lobo, G.J.; Zhou, J. Did conservatism in financial reporting increase after the Sarbanes-Oxley Act? Initial evidence. Account. Horiz. 2006, 20, 57-73. [CrossRef]

88. Xie, B.; Davidson, W.N., III; DaDalt, P.J. Earnings management and corporate governance: The role of the board and the audit committee. J. Corp. Financ. 2003, 9, 295-316. [CrossRef]

89. DeFond, M.L.; Jiambalvo, J. Debt covenant violation and manipulation of accruals. J. Account. Econ. 1994, 17, 145-176. [CrossRef]

90. Kasznik, R. On the association between voluntary disclosure and earnings management. J. Account. Res. 1999, 37, 57-81. [CrossRef]

91. Skinner, D.J.; Sloan, R.G. Earnings surprises, growth expectations, and stock returns or don't let an earnings torpedo sink your portfolio. Rev. Account. Stud. 2002, 7, 289-312. [CrossRef]

92. DeAngelo, L.E. Accounting numbers as market valuation substitutes: A study of management buyouts of public stockholders. Account. Rev. 1986, 61, 400-420.

93. Houqe, N.; van Zijl, T.; Dunstan, K.L.; Karim, A.K.M. Does corporate governance affect earnings quality: Preliminary evidence from an emerging market. AT Bus. Rev. 2011, 7, 48-57.

94. Hoang, T.C.; Abeysekera, I.; Ma, S. State ownership and earnings management: Empirical evidence from Vietnamese listed firms. In Proceedings of the 1st International Conference on Finance and Economics, Ho Chi Minh City, Việt Nam, 2-3 June 2014.

(C) 2020 by the authors. Licensee MDPI, Basel, Switzerland. This article is an open access article distributed under the terms and conditions of the Creative Commons Attribution (CC BY) license (http://creativecommons.org/licenses/by/4.0/). 